Scholarship Repository

University of Minnesota Law School

Articles

Faculty Scholarship

1993

\title{
Major Developments at the UN Commission on Human Rights in 1992
}

Joe W. (Chip) Pitts III

David Weissbrodt

University of Minnesota Law School, weiss001@umn.edu

Follow this and additional works at: https://scholarship.law.umn.edu/faculty_articles

Part of the Law Commons

\section{Recommended Citation}

Joe W. (Chip) Pitts III and David Weissbrodt, Major Developments at the UN Commission on Human

Rights in 1992, 15 Hum. RTS. Q. 122 (1993), available at https://scholarship.law.umn.edu/faculty_articles/ 230.

This Article is brought to you for free and open access by the University of Minnesota Law School. It has been accepted for inclusion in the Faculty Scholarship collection by an authorized administrator of the Scholarship Repository. For more information, please contact lenzx009@umn.edu. 


\section{Major Developments at the UN Commission on Human Rights in 1992}

Joe W. (Chip) Pitts III and David Weissbrodt*

\section{TABLE OF CONTENTS}

$\begin{array}{lll}\text { I. } & \text { INTRODUCTION } & 123 \\ \text { II. PARTICIPATION AT THE 1992 SESSION } & 125 \\ \text { III. } & \text { EFFECT OF ENLARGEMENT } & 126 \\ \text { IV. EFFORTS AT ENHANCEMENT } & 130 \\ \text { V. CONTINUING EFFECT OF COLLAPSE OF BERLIN WALL } & 134 \\ \text { VI. COUNTRY SITUATIONS } & 138 \\ \text { A. Afghanistan } & 138 \\ \text { B. Albania } & 139 \\ \text { C. Bahrain } & 139 \\ \text { D. Cambodia } & 139 \\ \text { E. Chad } & 140 \\ \text { F. Chile } & 140 \\ \text { G. China } & 140 \\ \text { H. Cuba } & 142 \\ \text { I. Cyprus } & 143 \\ \text { J. East Timor } & 143 \\ \text { K. El Salvador } & 144 \\ \text { L. Equatorial Guinea } & 145 \\ \text { M. Guatemala } & 146 \\ \text { N. Haiti } & 147 \\ \text { O. Iran } & 148 \\ \text { P. Iraq } & 149\end{array}$

* The authors would like to thank Dallas attorney Penny Parker, attorney Reed Brody (of International Human Rights Law Group and formerly of the International Commission of Jurists), research assistant Alya Kayal, and research assistant Peter-Christian Olivo for their assistance with this article. We would also like to thank Mead Data Central for Lexis/ Nexis research in connection with the article. 
Q. Israeli-Occupied Arab Territories

R. Lebanon

S. Myanmar (Burma) 152

T. Romania 153

U. Somalia 153

V. South Africa $\quad 154$

W. Sri Lanka $\quad 155$

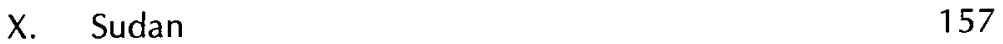

$\begin{array}{lr}\text { Y. Western Sahara } & 157\end{array}$

Z. Zaire 157

AA. Other Countries Not Considered 158

VII. THEMATIC MECHANISMS 158

A. Disappearances 158

B. Executions 161

C. Torture 163

D. Mercenaries 166

E. Religious Intolerance $\quad 168$

F. Arbitrary Detention 170

G. Children 172

H. Internally Displaced Persons $\quad 175$

VIII. OTHER ACTIONS OF THE COMMISSION 176

A. Work of the Sub-Commission 176

B. World Conference 179

C. Declaration on Disappearances 181

D. Declaration on Minorities 183

E. Emergency Response Mechanism $\quad 186$

F. Fair Trial 188

G. Advisory Services 189

H. Human Rights Defenders 191

1. Draft Optional Protocol to Torture Convention 192

J. Fact-finding and Forensic Science 193

K. AIDS and Other Disabilities 193

L. Other 194

IX. CONCLUSION 196

\section{INTRODUCTION}

The forty-eighth session of the United Nations Commission on Human Rights, the principal human rights organ of the United Nations, occurred at the Palais des Nations in Geneva, Switzerland from 27 January to 7 March 1992.' The session took place at a time of unprecedented invigoration of

1. For general reading about the Commission, see Penny Parker \& David Weissbrodt, Major Developments at the UN Commission on Human Rights in 1991, 13 Hum. Rts. Q. 573 
the United Nations in general, and demonstrated both the challenges and the opportunities facing the organization and its primary human rights arm in the world community today.

This session was the first involving the enlarged membership of the Commission (from forty-three to fifty-three countries, to remedy the underrepresentation of developing countries). A record number of nongovernmental organizations (NGOs) also attended. ${ }^{2}$ Instead of the Soviet Union, the Russian Federation participated. The Commission continued its debate over the enhancement of its effectiveness, in which the ideological divide between East and West largely dissolved, but North/South issues came to the fore. The Commission took a number of actions, and began a number of new initiatives, which bode well for its effectiveness in promoting and protecting human rights.

During the Commission session, the appointment of new Under-Secretary-General for Human Rights Antoine Blanca (France) was announced. Blanca will replace former Under-Secretary Jan Martenson (Sweden), who presided over a number of important initiatives of the Commission, and was a prime force behind the 1993 World Conference on Human Rights. A number of delegations paid homage to Martenson during the Commission, and at the end of the 1992 session the entire Commission gave Martenson an ovation and special recognition for his leadership in the promotion of human rights.

All-in-all, the Commission adopted eighty-three resolutions, and nineteen decisions, of which sixty-seven resolutions and seventeen decisions were by consensus. ${ }^{3}$ The most significant resolutions dealt with Afghanistan,

(Nov. 1991); Manfred Nowak, Country-Oriented Human Rights Protection by the U.N. Commission on Human Rights and its Sub-Commission, 21 Netherlands Y.B. of Int'l L. 39 (1991); Reed Brody, Penny Parker, \& David Weissbrodt, Major Developments in 1990 at the UN Commission on Human Rights, 12 Hum. Rts. Q. 559 (Nov. 1990); David Weissbrodt, Country-Related and Thematic Developments at the 1988 Session of the UN Commission on Human Rights, 10 Hum. Rts. Q. 544 (Nov. 1988); Howard Tolley, The UN Commission on Human Rights (1987).

Other informative articles on the developments at the 1992 Commission include, Highlights of the U.N. Commission of Human Rights (1992), 12 Quaker United Nations Office Geneva Newsletter 7 (May 1992); Reed Brody, Prosecution Is a Selective Business, 7 International Human Rights Law Group Docket 6 (Spring 1992); Koen M. Davidse, The 48th Session of the U.N. Commission on Human Rights and U.N. Monitoring of Violations of Civil and Political Rights (1992) (draft of proposed article on file with author); Martin MacPherson, Elizabeth Fetter, and Polly Stewart, United Nations Commission on Human Rights (1992), Friends of the World Committee for Consultation (May 1992); Liliana Valina, A Clance at the 48th Session on the Commission of Human Rights, 4 Newsletter of the Swiss Committee Against Torture 5 (April 1992); Adrien Zoller, After the Cold War: Analytical Report on the 48th Session of the Commission on Human Rights, in The International Service for Human Rights, Human Rights Monitor, No. 16 (April 1992) (hereinafter Zoller).

2. Zoller, supra note 1 , at 3 .

3. In 1991 the Commission adopted eighty-two resolutions and ten decisions, of which sixty-six resolutions and nine decisions were by consensus. 
Albania, Cuba, El Salvador, Equatorial Guinea, Guatemala, Haiti, Iran, Iraq, the Israeli-occupied territories including Palestine, Myanmar (Burma), Romania, South Africa, and Western Sahara. There were also two significant official statements regarding East Timor and Sri Lanka. The Commission broke new ground in standard-setting by approving the texts of Draft Declarations on the Rights of Minorities and on the Protection of Persons from Enforced Disappearances, as well as recommending them for adoption by the Economic and Social Council (ECOSOC) and the General Assembly. The Commission further requested the Secretary-General to investigate the viability of creating a standing team of forensic experts to assist in the exhumation and identification of victims of human rights violations, adopted a resolution on human rights and persons with disabilities, and set the stage for consideration and adoption next year of an "emergency response" mechanism for human rights violations. In addition, the Commission made some progress toward an Optional Protocol to the Convention against Torture and Other Cruel, Inhuman or Degrading Treatment or Punishment, which would call for a preventive system of visits to detention facilities.

The Commission must be faulted, however, for its failure to give adequate attention to the human rights situations in a number of countries. The most prominent example is the Commission's failure to pass a resolution condemning the violations in China, but other areas which were given inadequate attention include Columbia, Ethiopia, India, Indonesia (other than the limited attention to the situation in East Timor), Nagorno-Karabagh, Peru, the Philippines, Turkey, and Viet Nam. Although serious concern continued to exist regarding human rights violations in Syria, Syria was reportedly dropped from consideration under the Commission's confidential 1503 procedure, without objection from the United States. Also, little substantive content was added to the plans that already existed regarding the 1993 World Conference on Human Rights. Uncertainty regarding the location and prospects for the Conference persisted, as Germany withdrew its previous invitation to serve as host and concerns circulated in some quarters that the Conference might provide the opportunity for human rights violators to vitiate existing protective mechanisms.

Nevertheless, on balance the 1992 Commission was widely considered by governments and nongovernmental organizations as the most successful Commission in years.

\section{PARTICIPATION AT THE SESSION}

In the tradition of rotating Chairs of the Commission by region, Pal Solt (Hungary) was elected from the Eastern European region to serve as Chair of the session. Ronald Walker (Australia), Mohamed Ennaceur (Tunisia), and Sirous Nasseri (Iran) were elected as Vice-Chairs to represent their respective regions on the Commission's Bureau, and Ligia Galvis (Colombia) was 
elected as Rapporteur. Women were thus underrepresented again on the 1992 Commission Bureau.

The membership of the Commission was expanded in 1992 from fortythree members to fifty-three members. In addition, seventy observer governments from the ranks of United Nations members, and two governments that are not members of the United Nations (the Holy See, and Switzerland) attended the session. Sixteen specialized agencies and intergovernmental organizations, two nongovernmental political organizations (the PLO and the Pan Africanist Congress of Azania), and 140 nongovernmental human rights organizations attended. Foreign dignitaries from eighteen different nations or organizations addressed the Commission, including the Presidents, Prime Ministers, Vice-Presidents, and Foreign Ministers of a number of nations. ${ }^{4}$ These numbers reflect the continuing trend toward increased interest in the Commission's work, making the 1992 session the largest ever attended. ${ }^{5}$

Chair Pal Solt is to be commended for effectively managing the session. His strict insistence that explanations after the vote be given only after discussion on a particular item had ceased, kept disruptive interventions and posturing to a minimum. Also, by beginning night sessions early in the session, instead of late, the flow of work of the Commission was considerably smoother than usual.

\section{EFFECT OF ENLARGEMENT}

The effect of the Commission's enlargement from forty-three members to fifty-three members was the subject of great debate (and not insignificant

4. Duarte Ivo Cruz, Vice-Minister of Foreign Affairs of Portugal; Lennox M. Boyd, UnderSecretary of State for Foreign and Commonwealth Affairs of the United Kingdom; Omer Arteh Ghalib, Prime Minister of Somalia; Bernard Kouchner, Secretary of State for Humanitarian Action of France; Emeka Anyaoku, Secretary General of the Commonwealth; Habib Ben Yahia, Minister of Foreign Affairs of Tunisia; Dan Quayle, Vice-President of the United States; Ibrahim Badawi, President of the African Commission of Human and People's Rights; Augusto Blacker Miller, Minister of Foreign Affairs of Peru; Rene Felber, President of the Swiss Confederation and Chief of the Federal Department of Foreign Affairs; Bernd Niehaus, Minister of Foreign Affairs of Costa Rica; Andrei Kozirev, Minister for Foreign Affairs of the Russian Federation; Yasser Arafat, President of the Executive Council of the Palestine Liberation Organization; Hector Gros Espiell, Minister for Foreign Affairs of Uruguay; Jalal Ali Lufti, First President of the Court of Justice of Sudan; Mathieu Ngirumptse, Minister of Justice of Rwanda; Sadako Ogata, UN High Commissioner for Refugees; and Federico Mayor, Director-General of the United Nations Educational, Scientific and Cultural Organization (UNESCO).

5. For example, in 1991 there were forty-three member countries, seventy-two observer governments, four nonmember governments (including the two Koreas, which subsequently became members of the United Nations), thirteen specialized agencies and intergovernmental organizations, two nongovernmental political organizations, and 123 nongovernmental human rights organizations. 
concern) prior to its implementation. Six new representatives were added from Africa, four from Latin America, two from Asia, and one from Eastern Europe. ${ }^{6}$ The new African nations represented were Angola, Gabon, Kenya, Lesotho, Libya, and Nigeria; the new Latin American nations represented were Barbados, Chile, Costa Rica, and Uruguay; the new Asian nations represented were Iran and Syria; and the new East European nation represented was Bulgaria. Enlargement resulted from a series of initiatives aimed at more "equitable geographical distribution" in the United Nations, the most important early example of which was the 1989 General Assembly resolution to that effect. ${ }^{7}$ Certainly, there was a widespread perception that the developing nations were underrepresented vis-a-vis the developed nations.

Some of the concerns expressed prior to and even during the Commission revolved around the general impact that enlargement would have on the Commission's ability to take effective action. There was fear, for example, that the need for additional consensus would increase the difficulty of decision-making, and that the bigger regional blocs would aggravate the occasional tendencies of the Commission toward political polarization. There was also a general concern about the budgetary implications and time constraints stemming from enlargement, as well as the possible reduced effectiveness of the Commission from those logistical standpoints. Other concerns related to the human rights records of the specific nations proposed for new membership. In his address to the Commission, for example, Vice President Dan Quayle of the United States questioned whether it was appropriate for certain nations with poor human rights records (he singled out Iran, Iraq, and Cuba) to be members of the Commission and sit in judgment of other nations. ${ }^{8}$

For the most part, these concerns proved to be unfounded, at least for the time being. Financial issues remain significant for the Commission and for the United Nations generally, but the marginal incremental costs of enlargement were not seen as a major issue at the 1992 session. The timing concern proved to be overstated, and the benefits of a strict Chair to achieving the work of the Commission were evident in the 1992 session. This session

6. The 1992 Commission was thus composed of fifteen African countries (Angola, Burundi, Gabon, Gambia, Kenya, Lesotho, Libya, Madagascar, Mauritania, Nigeria, Senegal, Somalia, Tunisia, and Zambia), twelve Asian countries (Bangladesh, China, Cyprus, India, Indonesia, Iran, Iraq, Japan, Pakistan, the Philippines, Sri Lanka, and Syria), eleven Latin American countries (Argentina, Barbados, Brazil, Chile, Colombia, Costa Rica, Cuba, Mexico, Peru, Uruguay, and Venezuela), ten Western European and "Other" (WEO) countries (Australia, Austria, Canada, France, Germany, Italy, the Netherlands, Portugal, the United Kingdom, and the United States), and five Eastern European countries (Bulgaria, Czechoslovakia, Hungary, Russia, and Yugoslavia).

7. G.A. Res. 44/167 (1989).

8. U.N. Press Release HR/3023 (10 Feb. 1992). 
was the first in recent memory which did not have extended night meetings as a routine matter during the last weeks of the session, due to the Chair's use of night meetings early rather than later in the session, his strict enforcement of parliamentary rules including the rule allowing post-vote explanations of vote only after the vote, and his effective control of debate and points of order. One possible negative effect of this increased emphasis on timeliness could be a decline in NGO participation and fewer NGO statements, yet several complaints by NGOs to this effect during the 1992 session were offset in part by recognition that some of the joint NGO statements that resulted were more powerful and persuasive than individual NGO statements might have been.

Although there were concerns (and some concrete instances, often for economic or unique historical reasons) of regional bloc voting, the prevailing sentiment expressed by delegates from various regions was that a less ideological atmosphere seemed to exist at the Commission. In addition, Commission members, nonmember observer representatives, and representatives of nongovernmental organizations reported that the new members were relatively open-minded regarding new ideas and initiatives to enhance the effectiveness of the Commission. The new emphasis at the Commission on taking action regarding Asian human rights situations (e.g., Cambodia, East Timor, Myanmar, and Sri Lanka) is illustrative.

The need for increased efforts to achieve consensus opened up additional opportunities for new ideas and lines of communication, and thus new opportunities for effective action. Although the end result may have been a milder form of action, or a compromise text of a given resolution (for example), nations were open to taking action whereas in previous years political considerations made it much more difficult for them to act. The way the situations in East Timor and Sri Lanka were handled provide examples. In the case of East Timor, the Chair of the Commission issued a statement representing the consensus that the Commission was concerned about the human rights situation in that country. This statement was issued in lieu of a condemnatory resolution on the situation of East Timor. The Asian nations' opposition to a draft resolution ${ }^{9}$ in their region was certainly one factor that the resolution approach failed; but it is probably fair to say that in prior years that opposition would have been the death knell not only for a resolution, but for any effective action of the Commission. In the new environment, however, a compromise was possible that resulted in the innovative approach to East Timor further described below. A similar approach worked in the case of Sri Lanka.

As East-West ideological considerations decline in importance, it is not surprising that North-South considerations, international trade and business

9. Draft Resolution E/CN.4/1992/L.27 (withdrawn by sponsors, March 4, 1992). 
considerations, and the economic self-interest of nations, have all taken on greater significance. In its debate on economic, social, and cultural rights, the Commission seemed to be struggling to make such rights more tangible and concrete. This desire is reflected in the request in the Commission's resolution on the right to development that the Secretary-General continue to make concrete proposals for more effective implementation of the right to development, ${ }^{10}$ and the consequent report of the Secretary-General on the subject. " As another example, the primary resolution on economic, social, and cultural rights takes note with particular interest of work done on the right to adequate housing and on the use of social and economic indicators to measure the realization of such rights. ${ }^{12}$ The views of the South continue to predominate, however, in the Commission's resolutions on structural economic adjustment, foreign debt, and the right to development. ${ }^{13}$

With the recent tendencies of world trade against multilateral solutions and in favor of regional solutions, one might expect a powerful reinforcement of regional bloc voting within the Commission. The East Timor situation could again be an example of this trend, given the strong support Australia, Japan, and other Pacific Rim nations gave Indonesia in its opposition to the East Timor resolution. Yet it is worth noting that in an atmosphere of decreased ideology, economic considerations can definitely cut both ways. Despite the importance of regional trade, the continued importance of interregional trade may have been one reason that the Asian nations were willing to accede to the innovative European Community initiative that resulted in the statement read by the Chair regarding the consensus of the Commission expressing concern about the East Timor situation. ${ }^{14}$ The positive outcomes regarding Sri Lanka, East Timor, and a number of other Asian countries (e.g. Afghanistan, Burma, Cambodia) force one to discount the protective bloc voting thesis.

One example of the increased prominence of the North-South perspective coloring the Commission's actions can be found in the resolution on "fraudulent enrichment of top State officials."15 The resolution was designed to combat the problem of official corruption, but there was a con-

10. C.H.R. Res. 1992/13, 48 U.N. ESCOR Supp. (No.2) at 46, U.N. Doc. E/CN.4/1992/84 (1992).

11. U.N. Doc. E/CN.4/1992/10 (1992).

12. C.H.R. Res. 1992/10, 48 U.N. ESCOR Supp. (No.2) at 38, U.N. Doc. E/CN.4/1992/84 (1992).

13. See C.H.R. Res. 1992/9, 48 U.N. ESCOR Supp. (No.2) at 36, U.N. Doc. E/CN.4/1992/ 84 (1992); see also the Commission's resolution on Human Rights and Extreme Poverty, C.H.R. Res. 1992/11, 48 U.N. ESCOR Supp. (No.2) at 42, U.N. Doc. E/CN.4/1992/84 (1992).

14. Statement of the Consensus Regarding East Timor, March 4, 1992; see U.N. Press Release HR/3056 (4 Mar. 1992).

15. C.H.R. Res. 1992/50, 48 U.N. ESCOR Supp. (No. 2) at 118, U.N. Doc. E/CN.4/1992/84 (1992). 
troversial paragraph that stated that the "developed countries have a special responsibility to contribute diligently to the restitution to despoiled peoples of the funds which their leaders have extorted from them." Japan and other developed countries strongly objected to this paragraph (and even tried, but failed, to get it deleted on a vote), on the ground that official corruption was a worldwide problem, and not one for which developed as opposed to developing countries have a "special" responsibility. The seemingly unbalanced paragraph and the failure of the Japanese effort cannot be understood outside of the North-South conflict and the particular concern that bank secrecy laws in certain European countries are shielding the assets of corrupt present or former officials from developing countries.

The end of the cold war, the democratic revolutions in Eastern Europe and elsewhere, the continued recognition of the difficulties of keeping information about human rights violations silent in an age of instant communications and sophisticated NGOs, and the enhanced stature of the United Nations are all factors that help explain why the concerns regarding enlargement proved to be unfounded, for the most part. At the present time, these factors appear to be relatively permanent aspects of the international scene, likely to be influential until and unless new and dramatically different countervailing factors become significant. If the 1992 Commission is any indication, and to the extent that the factors mentioned above are some of the primary factors involved, enlargement of the Commission would not seem to be an obstacle to achievement in future years of at least the same degree of success (e.g., action taken regarding the human rights situation in twenty-two nations) achieved at the 1992 Commission.

\section{EFFORTS AT ENHANCEMENT}

Accompanying the debate over enlargement of the Commission during the past several years has been significant debate about enhancing the effectiveness of the Commission. As mentioned above, the issues were linked in many minds.

In 1990, a major but inconclusive debate took place between the countries of the North (basically the Western European and other countries (WEO) and the East European countries) and the Commission members of the South over the issue of the enhancement of the Commission's work. A working group that met during the session was unable to reach a consensus on any recommended changes. When, later that year, ECOSOC favored the South on the enlargement issue by expanding the membership of the Commission, it simultaneously accepted several enhancements urged by the North. These improvements included (1) allowing the Commission to meet exceptionally in urgent human rights situations where a majority of the Commission agrees that such a meeting is advisable, (2) recommending an extension of the terms 
of the thematic special rapporteurs from two years to three years, and (3) providing that the Commission's Bureau would meet during the week after the session to consider ways of improving the organization and work of the Commission. ${ }^{16}$

The debate over enhanced effectiveness continued in 1992. In 1991, the Commission decided that its agenda should be an important topic of discussion and that the Secretary-General should prepare a draft 1993 agenda in accordance with the guidelines contained in Commission Decision 1991/ 109. These guidelines streamline the Commission's agenda into eight major categories: (1) opening matters, (2) situations (occupied Arab territories, selfdetermination, and South Africa), (3) issues (economic, social, and cultural rights; right to development; status of international covenants; treaty bodies; and biennial issues), (4) country procedures (1503 procedures and public procedures), (5) thematic issues and procedures, (6) standard-setting, (7) further promotion of human rights, and (8) closing matters. Near the end of its 1992 session, the Commission adopted a decision pursuant to which it requested the approval of ECOSOC for those decisions of the Commission requiring ECOSOC approval. ${ }^{17}$

While reorganization of the agenda need not necessarily bring about significant substantive change in the work of the Commission, numerous comments during the Commission revealed concerns that such "streamlining" could adversely affect the Commission's effectiveness. On one hand, there were a number of comments by the United States (and occasionally by other delegations) that continued to reflect the perception on the part of developed nations in particular in favor of civil and political, as opposed to economic, social, and cultural rights. The United States was also concerned that the effectiveness of the Commission was being diluted by attention to issues that were only incidentally related to human rights, and were in the first instance related to economics, criminology, etc. For example, in the debate on economic, social, and cultural rights and the right to development, the United States reiterated its longstanding position that while such rights are not unimportant, civil and political rights are more important both inherently and in terms of creating the conditions for fulfilling economic rights. The United States thus recommended that the right to development could be pursued more fully in other United Nations fora, such as the United Nations Development Program. ${ }^{18}$

On the other hand, certain nations with poor human rights records often invoked the rationale of streamlining the work of the Commission in order

16. E.S.C. Res. 1990/48, U.N. Doc. E/1990/INF/6 at 80 (1990).

17. C.H.R. Dec. $1992 / 117$ (adopted without a vote, 5 Mar. 1992), 48 U.N. ESCOR Supp. (No. 2) at 214, U.N. Doc. E/CN.4/1992/84 (1992).

18. Statement of Ambassador J. Kenneth Blackwell, Head of U.S. Delegation to the Commission (5 Feb. 1992); see also U.N. Press Release HR/3017 (1992). 
to justify limitations on mechanisms that have proved effective. The comments of the representative of China on the issue of whether to extend the mandate of the Special Rapporteur on Torture, and the comments of the representative of Cuba as to the burden placed on small nations by the need to comply with the thematic procedures and other human rights mechanisms ${ }^{19}$ may be seen in this light. The arguments made by both nations for review of Commission procedures would be less suspect coming from other sources. Similarly, one might agree that promotion of human rights should be guided by the principles of "nonselectivity, impartiality, and objectivity," and "should not be used for political ends." ${ }^{20}$ Nonetheless, the reiteration in 1992 of these points of a 1991 resolution that included in its sponsors a number of nations with serious human rights problems, raises questions about the motives of some of the sponsors.

The Centre for Human Rights, based in Geneva but also maintaining an office at the New York headquarters of the United Nations, is of course a crucial actor in United Nations activities in the field of human rights. In addition to providing secretariat and administrative services to the Commission and to other organs of the United Nations active in the field, the Centre provides substantive services such as research regarding human rights problems and implementation, advisory services and technical assistance in the field of human rights, coordination with nongovernmental organizations and the media, publications, and special projects (such as the 1993 World Conference).

A major problem in the last several years has been the geometric increase in the workload of the Centre, without a concomitant increase in its personnel and budgetary resources. Virtually all the reports issued by thematic working groups and rapporteurs emphasized the "system overload" of the Special Procedures section of the Centre, in light of the increased workload and limited staff. ${ }^{21}$ It was more than a little ironic that while the Commission passed a resolution once again recognizing the important role played by the Centre and the need to provide it with adequate resources, ${ }^{22}$ an internal memo was issued during the Commission session announcing imminent layoffs of a number of key Centre personnel who for budgetary reasons were on short-term contracts. The funding crisis threatened to render meaningless the commitments contained in the Secretary-General's interim report to the Commission regarding approval in theory of funding for a net increase in

19. Statement of the Representative of Cuba on the need to reform thematic procedures ( 28 Feb. 1992).

20. C.H.R. Res. 1992/39, 48 U.N. ESCOR Supp. (No. 2) at 98, U.N. Doc. E/CN.4/1992/84 (1992).

21. See, e.g., U.N. Doc. E/CN.4/1992/17 (1992), at 5 (Report of the Special Rapporteur on Torture).

22. C.H.R. Res. 1992/53, 48 U.N. ESCOR Supp. (No. 2) at 124, U.N. Doc. E/CN.4/1992/84 (1992). 
positions at the Centre. ${ }^{23}$ At the time of publication of this article, however, the crisis had apparently abated through an exemption of the Human Rights Centre from the hiring freeze and layoffs affecting many other United Nations personnel.

The thematic procedures and reports generally continued to grow in strength and stature during the year leading to the 1992 Commission meeting. ${ }^{24}$ The Commission added a recommendation that governments permit follow-up visits in order to further enhance the effectiveness of the recommendations of the thematic rapporteurs or working groups. ${ }^{25}$ Two other new developments can be expected to advance the effectiveness of the thematic procedures: (1) the Commission's request that the thematic special rapporteurs and working groups highlight problems of responsiveness in their reports (which was done, for example, in the report of the Special Rapporteur on summary or arbitrary executions), and (2) the request that the Secretary-General, in close contact with the thematic rapporteurs and working groups, issue an annual compilation of their general recommendations. ${ }^{26}$ The idea of a compilation of the general recommendations apparently originated with the Czechoslovakian government, in consultation with some of the major NGOs, and should facilitate implementation of relevant recommendations. Finally, the Commission's resolution condemning acts of intimidation and reprisal against people who cooperate with United Nations human rights representatives is also intended to strengthen the effectiveness of the thematic mechanisms. ${ }^{27}$

At the beginning of the 1992 session, it was thought that the Commission would possibly implement a new human rights mechanism (either a working group or an independent expert) relating to internally displaced persons. After negotiations, it proved impossible to create such a mechanism in 1992, but the Commission did request the Secretary-General to designate a representative to study the issue further and present the study to the Commission at its next session. ${ }^{28}$ The Commission did, however, receive the report of the International Workshop on National Institutions for the Promotion and Protection of Human Rights, ${ }^{29}$ including the principles relating to such institutions. The Commission resolved to transmit those principles, which affirm the beneficial advisory role of national human rights institutions, and their

23. U.N. Doc. E/CN.4/1992/75 (1992).

24. C.H.R. Res. 1992/41, 48 U.N. ESCOR Supp. (No.2) at 103, U.N. Doc. E/CN.4/1992/84 (1992).

25. $l d$.

26. $I d$.

27. C.H.R. Res. 1992/59, 48 U.N. ESCOR Supp. (No.2) at 138, U.N. Doc. E/CN.4/1992/84 (1992).

28. C.H.R. Res. 1992/73, 48 U.N. ESCOR Supp. (No.2) at 173, U.N. Doc. E/CN.4/1992/84 (1992).

29. U.N. Doc. E/CN.4/1992/43 and Add. 1 and 2 (1992). 
broad range of concerns, to the General Assembly (through ECOSOC) for adoption. $^{30}$

The Commission also continued to consider ways to enhance the effectiveness of its Sub-Commission, which are further discussed in Section VIII. A. below.

As always, the reforms to enhance the Commission's effectiveness, like the Commission's work itself, may have proceeded incrementally in 1992, but proceeded nonetheless.

\section{CONTINUING EFFECT OF COLLAPSE OF BERLIN WALL}

In the opening statements to the Commission, each speaker including former Chair Enrique Bernales Ballesteros (Peru), former Under-Secretary for Human Rights Jan Martenson, and incoming Chair Pal Solt (Hungary) highlighted the decline of ideological factors in international relations. Bernales emphasized that the ferment accompanying the crumbling of ideological walls sometimes gave rise to "xenophobia, nationalism and racism," but also opened up new lines of communication and cooperation with the potential of strengthening human rights. ${ }^{31}$ Former Under-Secretary for Human Rights Jan Martenson echoed these points, but also spoke of the "worldwide human rights revolution" that came in the wake of the decline in EastWest conflict. ${ }^{32}$ This revolution and the opening up of previously rigid political systems naturally resulted in new risks and conflicts, on one hand, but also new freedom, on the other hand. As new Chair Pal Solt put it, the "fifty years of antagonism and ideological confrontation had [virtually] come to an end." ${ }^{\prime 33}$ The "questions that were once examined on an ideological basis, ... were now approached in a pragmatic manner." ${ }^{34}$

Ideological considerations are not, however, irrelevant at the Commission. The entire existing structure of economic, social and cultural rights, on the one hand, and civil and political rights, on the other, is an artifact of prior ideological battles between the East and West. Ideological considerations and groupings also continue to be used, but much less effectively, as an attempted smokescreen for actions that are more explicable on practical (or self-interested) grounds. The resolution on "impartiality" in Commission actions, which includes among its sponsors a number of human rights violators and most of the nations continuing to cling to some version of Com-

30. C.H.R. Res. 1992/54, 48 U.N. ESCOR Supp. (No.2) at 125, U.N. Doc. E/CN.4/1992/84 (1992).

31. U.N. Press Release HR/3005 (27 Jan. 1992), at 1-2.

32. $l d$.

33. Id.

34. Id. 
munism or Marxism, falls into this category. ${ }^{35}$ Ideology plays a part, also, in the sometimes unseemly and chauvinistic comments of representatives of some Western nations regarding the "victory" of the West in the Cold War. Some elements of this attitude were present in the address of United States Vice President Quayle to the Commission, which also singled out mainly nations that were within the former Soviet Union's sphere of influence. ${ }^{36}$ Richard Schifter's speech on China also reflected an ideological approach to human rights. Another example of the lingering effect of ideology may be the difficulties that Hungary had getting its nominee elected to the Sub-Commission (the expert from Hungary eventually lost); some speculated that Hungary was perceived by some nations as having "sold out" to the West.

The main continuing significance of the East/West ideological conflict, however, arises when substantive North/South issues happen to overlap with previous East/West issues (e.g. when an economically less developed nation is a human rights violator that subscribes to some degree to Communist or Marxist ideology). The failure of the Commission to pass a resolution on China, discussed in further detail under "Country Situations," below, may be seen as influenced by the convergence of a number of factors, including nostalgia for Marxism, resentment over North/South issues, general residual anti-Western sentiment, regional/economic solidarity, and (above all) strategic/tactical errors in approaching the issue.

Despite the continued (but reduced) relevance of ideological conflict at the Commission, however, the speakers opening the session were correct: the 1992 Commission was reviewing the human rights situation in a world that had undergone historic changes. Perhaps, the most significant feature of the new landscape was the removal of the Soviet Union from the map, and its replacement by the new Commonwealth of Independent States (CIS). (Only a year before, in the spring of 1991, the Soviet Union was a continued object of concern by the Commission due to the tragic acts of violence in the Baltics, especially Latvia and Lithuania.) There were also developments toward peace and stability in many regions of the world which had long been subject to armed conflict stemming at least in part from the Cold War. Peace had come to Kuwait, for example, whereas the Persian Gulf War was raging during the previous Commission session. Just before the $1992 \mathrm{Com}-$ mission began, too, new peace accords were signed in El Salvador. The Madrid Peace Process had started with respect to Israel and the Palestinians. And in Afghanistan, the easing of tensions between East and West had resulted in a joint US/CIS statement that significantly reinforced moves toward a

35. C.H.R. Res. 1992/39, 48 U.N. ESCOR Supp. (No. 2) at 98, U.N. Doc. E/CN.4/1992/84 (1992).

36. See U.N. Press Release HR/3023 (10 Feb. 1992). 
settlement of the Afghan conflict. In light of the increased violations of human rights that take place in times of armed conflict, these developments were good news for the Commission's project of promoting and protecting human rights.

The collapse of the Berlin Wall had particular effect in encouraging tolerance of religious belief, as strictures in Eastern Europe and other areas under Soviet influence fell by the wayside along with one-party dominance. The report of the Special Rapporteur on Religious Intolerance called attention to the positive developments in this regard in the former Soviet Union, Albania, Bulgaria, Poland, and Czechoslovakia-all of which have introduced measures designed to enhance religious freedom, ranging from allowing the reintroduction of Christmas as a public holiday to the repeal of discriminatory legislation outlawing certain religions or religious "sects." ${ }^{137}$

Yet the "new pragmatism" mentioned by Commission Chair Pal Solt in his opening speech has implications with negative as well as positive potential for international relations and the level of human rights violations. The end of the Cold War was accompanied by power vacuums and concomitant chances of increases in civil unrest and armed conflict as nations and groups within nations try to fill those power vacuums in pursuit of what they perceive to be their interests. The Commission has always had before it a large number of situations involving armed conflict, but it is possible that the Commission could be reviewing an increasing number of such situations in future years as a result of the end of the Cold War. Examples include the complex situation in the former Soviet Union, in Yugoslavia, Ethiopia, and North/South Korea. (The particular significance of the Commission adopting at this time the Draft Declaration on Minorities, further discussed in Section VIII.D. below, stems from the responsiveness of the Declaration to these topical issues.)

The positive and negative implications of the reduction in ideology extend to the work of the Commission as well. On the positive side, the toned-down rhetoric and diminished procedural posturing enhances the chances of substantive dialogue and action. By way of example, the choice of J. Kenneth Blackwell, former Mayor of Cincinnati, to continue his service as Head of the United States delegation, reflects a new seriousness about tackling the human rights situations around the world with less ideological selectivity. Ambassador Blackwell has a long and distinguished career of public service at all levels of government, and experience dealing with a wide range of substantive issues. This appointment is in contrast to the head of delegation for the United States from 1988 until 1991, Armando Valladares, a former Cuban political prisoner whose choice reflected the ideological priorities of the United States at the time. In his second year of service

37. See U.N. Doc. E/CN.4/1992/52 (1992), at 175. 
at the Commission, Ambassador Blackwell consolidated his reputation among both governments and NGOs alike as a highly intelligent and savvy diplomat with a talent for achieving practical results.

The primary positive effect on the Commission of the reduced ideological tension, however, is the new atmosphere of cooperation that prevails. Nations are less inclined, and less able, to shield human rights violations behind a veil of world politics. Consensus is easier to achieve on the various matters before the Commission; existing lines of communication have been strengthened and new lines opened; and new opportunities are being found in terms of forging new majorities, crossing former ideological and regional boundaries, and taking more effective action. This new atmosphere results in action on countries that were previously difficult or impossible to consider, often involving remarkable coalitions (Russia, the United States, and Eastern Europe now vote together on most issues). The most prominent example of such country action involved Myanmar (Burma), discussed below. Regional groups split their votes on a number of significant resolutions of the Commission, including, for example, resolutions on China, Cuba, Iran, and Iraq.

Regional groups have, however, become more assertive in the wake of the Cold War. Asia, Latin America, and the European Community were all noticeably more assertive at the 1992 Commission. The 1992 session was the first international forum at which the European Community tested the principle of common policy coordination in accordance with the intent behind the Maastricht Treaty (see discussion of China, below). Regional groupings are likely to become even more assertive in the future, as power continues to disperse from the bipolar paradigm that previously existed.

Consensus resolutions were possible in a number of new instances (e.g., South Africa); the resolution on Albania was joined by the government of Albania, and for the second year in a row was adopted by consensus (whereas in previous years it has always been adopted only by a split vote). The Russian vote to condemn Cuba for its human rights violations ${ }^{38}$ was an especially significant example of the new climate of cooperation, and United States Ambassador Blackwell highlighted this development in his postCommission press conference.

In short, as a result of the collapse of the Berlin Wall and the succeeding international changes, the Commission is more effective than ever. As discussed below in Section VIII.G., the advisory services of the Centre for Human Rights since 1988 have played a significant role in drafting new constitutions and legislation for, and providing technical assistance to, the newly democratic governments emerging from the former Soviet Union. Governments such as Albania are now cooperating with the Commission and its special

38. C.H.R. Res. 1992/61, 48 U.N. ESCOR Supp. (No.2) at 141, U.N. Doc. E/CN.4/1992/84 (1992). 
procedures, and with the exception of a few holdouts like Cuba and China, that tendency is expected to continue. The Commission's work is also enhanced by the decreased number of interventions by NGOs and governments, also attributable in part to the more limited effects of ideology. (The authors estimate that there were approximately 20 percent fewer interventions per topic at the 1992 Commission than during the previous year's session.) The newly cooperative environment means not only that the Commission is more effective, but that prospects for enhancing its effectiveness still further are better than ever.

\section{COUNTRY SITUATIONS}

The most significant countries and regions on which the Commission took action, or significantly failed to take action, are as follows:

\section{A. Afghanistan}

In its primary resolution on the country situation in Afghanistan, ${ }^{39}$ adopted without a vote, the Commission underlined the importance of the SecretaryGeneral's May 1991 five-point peace plan for Afghanistan, and his initiatives since that time, welcomed the judicial reforms undertaken by the Afghan authorities, welcomed releases of political prisoners, and renewed the mandate of the Special Rapporteur Felix Ermacora (Austria) for another year. The resolution also, as in previous years, urged all parties to the Afghan conflict to respect humanitarian rules, to protect all prisoners from acts of reprisal and violence, and urged all parties to increase their efforts to achieve a comprehensive political solution in order to bring about peace and full restoration of human rights in Afghanistan. In the course of its consideration of the right to self-determination, the Commission adopted another resolution, ${ }^{40}$ also by consensus, in which it emphasized the importance of the Agreements on the Settlement of the Situation Relating to Afghanistan, concluded at Geneva on 14 April 1988, expressed its appreciation to the Secretary-General and his Personal Representative for their "constant efforts" to achieve a political solution to the problem, and reaffirmed the right of the Afghan people to self-determination. ${ }^{41}$

39. C.H.R. Res. 1992/68, 48 U.N. ESCOR Supp. (No.2) at 159, U.N. Doc. E/CN.4/1992/84 (1992).

40. C.H.R. Res. 1992/5, 48 U.N. ESCOR Supp. (No.2) at 29, U.N. Doc. E/CN.4/1992/84 (1992).

41. $I d$. 


\section{B. Albania}

Due to the holding since the 1991 Commission of the first general elections in Albania and the substantial improvement of the human rights situation there, the Commission's 1992 resolution on the country, ${ }^{42}$ adopted without a vote, was slightly more moderate in tone. For example, instead of stating that the human rights situation in Albania remained a cause for concern, the resolution stated that "certain aspects" of the human rights situation remained a cause for concern. The resolution called for continuation of the legislative and administrative reforms that were oriented toward establishing respect for international human rights, democracy, and the rule of law. It also focused on one of the continuing human rights issues in Albania, namely the need to insure the political participation and respect for the rights of all persons belonging to minorities who live in Albania.

In addition, the Commission for the first time welcomed the cooperation of the Albanian government with the Commission. (In previous years, the Albanian government had been notoriously uncooperative.) This new spirit of cooperation manifested itself in a very tangible way during the Commission session-Albania and the Centre for Human Rights reached an agreement for United Nations technical assistance and advisory services. ${ }^{43}$

\section{Bahrain}

The Commission's five member Working Group on Situations (this year consisting of representatives from China, Columbia, Ghana, Hungary, and the United States) met just prior to the opening of the Commission session to make recommendations regarding those nations which had been the subject of confidential communications under the Commission's 1503 procedure.

The situation in Bahrain was submitted to the Commission, which decided to keep Bahrain under consideration for another year. ${ }^{44}$

\section{Cambodia}

Noting the significance of the Paris Agreements on a Comprehensive Political Settlement of the Cambodian conflict, the Commission in 1992 adopted a

42. C.H.R. Res. 1992/69, 48 U.N. ESCOR Supp. (No.2) at 163, U.N. Doc. E/CN.4/1992/84 (1992).

43. $1 d$.

44. Zoller, supra note 1 , at 17. 
decision without a vote commending all parties and countries which contributed to the Agreements, welcoming the fundamental importance given in the Agreements to substantive human rights provisions, and encouraging both the United Nations Transitional Authority in Cambodia and the Centre for Human Rights in their respective human rights activities in Cambodia. ${ }^{45}$

\section{E. Chad}

For the second year in a row the Commission considered the human rights situation in Chad under the confidential 1503 procedure. While the Commission reportedly considered that a number of the cases submitted regarding Chad warranted further explanation, it was thought that the new government in Chad should have additional time to provide more details. ${ }^{46}$ The Commission thus decided by consensus to keep the situation in Chad under consideration next year.

\section{F. Chile}

For the first time in years, due to the substantial improvement in the human rights situation in Chile, the Commission took no action and paid no special attention to Chile, which also happened to be a new member of the Commission.

\section{G. China}

China proved to be the most difficult situation at the 1992 Commission, and the most significant failure of the Commission. Especially since the suppression of the pro-democracy movement in Tiananmen Square during June 1989, the serious human rights violations in China have been the cause of grave concern both to other nations and to NGOs. Unfortunately, the Commission has been unable to act in the intervening years, perhaps because of the inherently political nature of an organization whose voting membership is composed exclusively of governmental representatives. Hence, in 1990 the Chinese government through its strenuous lobby was able to defeat a resolution which had originated in the Sub-Commission, by a procedural maneuver of a "no action" vote which narrowly passed (by a vote of sev-

45. U.N. Dec. 1992/102, 48 U.N. ESCOR Supp. (No.2) at 208, U.N. Doc. E/CN.4/1992/84 (1992).

46. Zoller, supra note 1 , at 18 . 
enteen in favor, fifteen against, and eleven abstaining). In 1991, no resolution at all was introduced.

The approach to China at the 1992 Commission was flawed from the outset. Looking for the first opportunity to exercise the coordinated approach to policy implicit in the Treaty of Maastricht, the European Community seized upon the situation in Tibet (after strong urging by the Tibetan lobby). In addition, the Sub-Commission, by a close secret ballot vote of nine in favor, seven against, and four abstentions, had called upon China to respect the human rights of the Tibetan people, and requested the Secretary-General to gather information on the situation in Tibet, ${ }^{47}$ which the Commission had before it in the form of a thorough note from the Secretary-General. ${ }^{48}$ The Sub-Commission resolution resulted in a resolution sponsored by the European Community, almost wholly based on a draft resolution from the Tibetan lobby that had circulated earlier, entitled "Situation in Tibet." Apparently, however, the European Community had not coordinated its approach in the matter with either the United States or a number of other countries or regions. Most African delegations had reportedly arrived in Geneva with firm instructions not to support a resolution on China..$^{49}$ And the strong reliance of the sponsors on the approach suggested by the Tibetan lobby made the draft resolution politically problematic.

The main problem that the United States had with the resolution was that it conflicted with the long-standing "One China" policy of the United States. The head of the US Delegation, Ambassador Blackwell, was careful to point out in his post-Commission press conference ${ }^{50}$ that the United States had mentioned China in its press conference on the first day of the Commission, and came to the Commission willing to work to forge a majority resolution on China generally (as opposed to Tibet by itself). Additionally, Assistant Secretary of State Richard Schifter visited the Commission midsession in large part to deliver a statement condemning the human rights violations in $\mathrm{China}^{51}$ (which, curiously, avoided mentioning the name of the country). Schifter's speech, with its failure to mention the country that was its subject, was symbolic of the actual ambivalence of United States policy toward China, and differences between the executive and legislative branches (and within each branch) on the subject. Despite occasional rhetoric against human rights violations, the United States has simultaneously pursued diplomatic and trade initiatives, such as President Bush's consistent support of most favored nation status for China. (During the Commission, President Bush vetoed legislation putting conditions on that status.) As a

47. Sub-Commission Res. 1991/10 (1991).

48. U.N. Doc. E/CN.4/1992/37 (1992).

49. Zoller, supra note 1 , at 24 .

50. Statement of Ambassador Kenneth Blackwell in Press Conference, 6 Mar. 1992.

51. See U.N. Press Release HR/3038 (20 Feb. 1992). 
result, the United States could not support a resolution simply styled "Situation in Tibet," because such a resolution arguably called into question the sovereignty of China over the region.

The compromise adopted was to title the resolution "Situation in China/ Tibet," and to broaden the preambular language and operative paragraphs from their exclusive focus on Tibet to more general references to China. Although these changes enabled the United States to support the resolution, and extensive lobbying ensued on both the Chinese side and the side of the sponsors of the resolution, the United States and other countries could have dedicated more effort toward the lobbying effort. In fact, the resolution was delayed for several days as lobbying took place.

When Portugal introduced the resolution on behalf of the European Community and debate began, China spoke against the resolution on the grounds that it was politically motivated and that its real objective was to undermine China's national sovereignty and reinforce the Tibet separatist movement. Pakistan then urged its no-action motion on similar grounds, to which it added China's cooperation with the Commission. Pakistan's motion was supported by similar statements from Cuba, Syria, Libya, Sri Lanka, Gambia, Mauritania, and Iran. It was opposed by statements from the United States, Portugal, the Netherlands, and Costa Rica-all of which urged that the resolution be considered on its merits. Yet Pakistan's no-action motion passed twenty-seven in favor, fifteen opposed, and ten abstaining. Almost all of the African countries supported Pakistan's motion; only Gabon and Senegal abstained. This result made for one of the most embarrassing moments of the Commission, when China and a number of its supporters among the Commission members expressed glee at the defeat of the WEO group.

In his concluding press conference, Ambassador Blackwell recognized in retrospect that it had probably been a tactical error to include Tibet in the name of the resolution, because the focus on Tibet reinforced China's argument that its national sovereignty and territorial integrity were being threatened-traditionally strong arguments at the Commission.

The failure in China was the primary example of the traditional limitations of the Commission, although most of the delegations thought that a more coordinated and considered approach on China could have yielded a different result, and should be able to do so in 1993.

\section{H. Cuba}

In its 1992 resolution on Cuba, the Commission expressed disappointment that the government of Cuba failed to address the concerns of the Commission expressed in its previous resolutions and decisions, and noted both the uncontradicted reports of continuing human rights violations in Cuba as well as the lack of cooperation from the Cuban government, particularly its refusal 
to allow the Special Representative of the Commission (Rafael Rivas PosadaColumbia) to visit Cuba in order to fulfill his mandate. Cuba continues to be increasingly isolated. Whereas in previous years, the Latin Americans had proposed weaker resolutions as alternatives to the United States effort, no such alternative was proposed in 1992. Accordingly, the Commission decided by a vote of twenty-three (including, for the first time, Russia) in favor, eight against, and twenty-one abstentions to increase the level of scrutiny of Cuba one notch by appointing a Special Rapporteur instead of the Special Representative that previously existed..$^{52}$

\section{Cyprus}

The Commission once again decided to postpone debate on the problems associated with the Turkish occupation of part of Cyprus. ${ }^{53}$ The SecretaryGeneral filed a report putatively updating the Commission on his efforts to negotiate a settlement between Greece and Turkey, but actually providing little new information. ${ }^{54}$ Turkey also filed a written note in reply to the allegations of the Greek Cypriots. ${ }^{55}$

\section{J. East Timor}

The violent incident on 12 November 1991 in which the Indonesian security forces killed and wounded a large number of civilians in Dili, East Timor, galvanized the international human rights community and resulted in an attempted resolution sponsored by the European Community and several other countries. East Timor had also received attention in the report of the Special Rapporteur on Torture, who had been made aware of a number of incidents of torture, many of which remained inadequately addressed by the Indonesian government. ${ }^{56}$ The Special Rapporteur on Torture had also made a special trip to Indonesia and East Timor at the invitation of the Indonesian government, and issued a special report with recommendations on the subject. ${ }^{57}$

Due to strong lobbying by the Indonesian government, supported by the Asian nations generally and especially Japan and Australia, it became

52. C.H.R. Res. 1992/61, 48 U.N. ESCOR Supp. (No.2) at 141, U.N. Doc. E/CN.4/1992/84 (1992).

53. C.H.R. Dec. 1992/106, 48 U.N. ESCOR Supp. (No.2) at 210, U.N. Doc. E/CN.4/1992/ 84 (1992).

54. U.N. Doc. E/CN.4/1992/25 (1992).

55. U.N. Doc. E/CN.4/1992/3 (1992).

56. U.N. Doc. E/CN.4/1992/17 (1992).

57. U.N. Doc. E/CN.4/1992/17/Add.1 (1992). 
clear that a resolution and even a decision of the Commission would be impossible. The seriousness of concern over the human rights situation in East Timor, however, meant that the European Community and a number of other Commission members were adamant that some action be taken. As a result of the leadership role played by Portugal, the outcome was an innovative consensus statement in which the Commission noted with serious concern the situation in East Timor and stated that it deplored the violent incident in Dili on 12 November $1991 . .^{58}$ The statement, however, welcomed the early action of the Indonesian government in setting up a national commission of inquiry and commended the government for its announcement that some members of the armed forces had been disciplined and that others would be subjected to military court proceedings. The Commission also welcomed the appointment of Amos Wako as Personal Envoy of the Secretary-General to obtain clarification of the tragic events of 12 November, and encouraged the Secretary-General to continue his good offices for achieving a just and comprehensive peace settlement in East Timor. Finally, the statement requested the Secretary-General to continue to follow the situation in East Timor, and to keep the Commission informed at its next session..$^{59}$

The legal effect of the statement on East Timor remains somewhat uncertain, but was made less so by a joint letter between the representatives of the governments of Indonesia and Portugal, addressed to the Secretary of the 48th Session of the Commission, making it clear that the operative paragraph on the Secretary-General's role would be fulfilled by submission of a written report to the Commission at its next session. Hence, an original way of maintaining scrutiny of a significant human rights situation in the world was created at the 1992 Commission. ${ }^{60}$

\section{K. El Salvador}

Just prior to the beginning of the 1992 Commission, the government of El Salvador and the Farabundo Martí Liberation Front (FMLN) signed peace accords that brought an end to the civil war that had plagued the country for the previous decade. In its consensus resolution on El Salvador, therefore, the Commission welcomed the peace accords and their provisions for unrestricted respect for human rights, acknowledged the important role of the good offices of the UN Secretary-General in achieving the peace accords,

58. Statement of the Commission on the Situation of Human Rights in East Timor (4 Mar. 1992).

59. Id.

60. Many NCOs and commentators, however, were disappointed the outcomes regarding East Timor (and Sri Lanka). See, e.g., Zoller, supra note 1, at 25. 
thanked its Special Representative Jose Antonio Pastor Ridruejo (Spain) for his final report on the situation of human rights in El Salvador, and requested the Secretary-General to appoint an independent expert to assist the human rights process in El Salvador and report to the Commission at its next session. ${ }^{61}$

In the final paragraph of its resolution, the Commission decided to move its consideration of the situation of human rights in El Salvador from Item 12 of its agenda (gross violations of human rights) to Item 19 of its agenda (advisory services), provided that there is the substantial improvement in the human rights situation that the parties expect. ${ }^{62}$

\section{Equatorial Guinea}

Although the government of Equatorial Guinea had been receiving advisory services relating to human rights for some time, the results have been disappointing. The report of the Commission's independent expert, Fernando Volio Jimenez (Costa Rica), reveals a pattern of continued human rights violations, and a disturbing pattern of inaction by the government of Equatorial Guinea. ${ }^{63}$

The 1982 Plan of Action proposed by the United Nations and accepted by the government of Equatorial Guinea has never been satisfactorily implemented despite the assistance given by the Centre for Human Rights. Although the government promulgated protective legislation in the field of human rights, it was not given practical effect with respect to the daily lives of citizens. In addition, the periodic reports due from the government of Equatorial Guinea to the Committee on Economic, Social and Cultural Rights and the Human rights Committee are all overdue. Further, systematic violations of human rights have persisted; the political situation has deteriorated; and the new Fundamental Law and other new laws in the area of religious freedom, amnesty, and political parties were prejudicial to the enjoyment of human rights and discouraged the return of the thousands of exiles.

In its stronger 1992 resolution on the country situation, ${ }^{64}$ the Commission by consensus commended its expert for his report on the situation in Equatorial Guinea, and expressed its concern at specific elements of the deteriorating human rights situation in the country. These elements included the persistence of arbitrary arrests, torture, the problematic situation of women,

61. C.H.R. Res. 1992/62, 48 U.N. ESCOR Supp. (No.2) at 143, U.N. Doc. E/CN.4/1992/84 (1992). Some governments (e.g., Portugal) and NGOs expressed the opinion on the floor that it was too early to end the mandate of the Special Representative.

62. Id.

63. See U.N. Doc. E/CN.4/1992/51 (1992).

64. C.H.R. Res. 1992/79, 48 U.N. ESCOR Supp. (No.2) at 195, U.N. Doc. E/CN.4/1992/84 (1992). 
the arbitrary detentions of exiles and opponents of the government who returned on the basis of promises of political opening, and the practice of using military courts for trying ordinary offenses. The Commission then proceeded in its resolution to call upon the government to free all political prisoners, to take measures and pass genuine legislative reforms to protect fundamental human rights of all citizens, to facilitate the return of all refugees and exiles, and to initiate negotiations with the opposition for establishing a democratic process in Equatorial Guinea. In addition, the resolution called upon the Chairman, in consultation with the Bureau, to appoint a person of recognized standing as an expert of the Commission, to make a thorough study of the violations of human rights by the government of Equatorial Guinea, and to report to the Commission at its next session. The Commission also decided (for the first time in the context of Equatorial Guinea) to consider the country next year under Item 12 (gross violations) instead of Item 19 (advisory services), unless there was significant improvement in the human rights situation. ${ }^{65}$

\section{Guatemala}

In 1990, the Commission created a new hybrid monitoring/advisory method for dealing with the situation in Guatemala: an independent expert who examines the situation in the country and simultaneously supervises the provision of advisory services. ${ }^{66}$ The Commission in 1992 decided once again to continue this mechanism, as it had in 1991. Last year, however, the Commission left open the issue of whether Guatemala would be considered under the advisory services item, or under the gross violations item.

The 1992 report of the expert (Christian Tomuschat-Germany) indicated that serious human rights violations continued in Guatemala, including numerous incidents of arbitrary executions, disappearances, and torture. ${ }^{67}$ Nonetheless, a strong lobbying effort on behalf of the WEO nations to have Guatemala considered under the gross violations item, as opposed to the advisory services item, was defeated-reportedly due, as in previous years, to strong opposition from the Latin American nations. ${ }^{68}$

Argentina, as coordinator of the "Rio Group" of democratic Latin American states, introduced the 1992 resolution, which was adopted without a vote. The operative language of the resolution, however, was more detailed and expressed greater frustration at the persistence of serious human rights

65. Id.

66. C.H.R. Res. 1990/80, 46 U.N. ESCOR Supp. (No.2) at 165, U.N. Doc. E/CN.4/1990/94 (1990).

67. U.N. Doc. E/CN.4/1992/5 (1992).

68. Zoller, supra note 1 , at 18 . 
violations than the resolutions of previous years. ${ }^{69}$ Among the new items emphasized by the resolution was the encouragement given to the government and to the Unidad Revolucionaria Nacional Guatemalteca to continue their negotiations in accordance with the 1991 Mexico and Queretaro agreements, and to ensure the full enjoyment of human rights by concluding a specific agreement on that subject as early as possible. The resolution more strongly exhorted the government to intensify its efforts at legal reforms and at investigations aimed at identifying and bringing to justice those responsible for violations of human rights, and in specific to implement the recommendations of the independent expert, especially with respect to abolition of the Civil Self-Defense Committees. ${ }^{70}$ The resolution once again left open the agenda item (gross violations or advisory services) under which the question of Guatemala would be considered at its next session.

The many persuasive statements by NGOs-over forty, by one count ${ }^{71}-$ on the continued abuses in Guatemala, led Portugal on behalf of the European Community, and Canada, to explain after the consensus vote that they would have preferred consideration of Guatemala under the gross violations item as opposed to the advisory services item. While they were impressed by the consensus and appreciated the efforts of the Latin Americans to achieve a negotiated text, they made clear that they would closely follow the Guatemalan situation, and only substantial improvement would warrant continued consideration under the advisory services item.

\section{N. Haiti}

Since the 1991 Commission, Haiti had experienced a violent coup d'etat in which the military overthrew democratically-elected President Jean-Bertrand Aristide, lives were lost, and human rights violated on a large scale. President Aristide's address to the Commission on 27 February passionately condemned the coup, and eloquently spoke of the importance of peaceful processes and respect for human rights in constitutional governments. He pledged his own continued commitment to human rights, pledged that the perpetrators of human rights violations in Haiti would not be treated with impunity, and called for a Special Rapporteur to investigate human rights violations in Haiti. ${ }^{72}$ In introducing his report ${ }^{73}$ to the Commission, expert Marco Tulio Bruni Celli (Venezuela) stated that Aristide had made serious

69. C.H.R. Res. 1992/78, 48 U.N. ESCOR Supp. (No.2) at 192, U.N. Doc. E/CN.4/1992/84 (1992).

70. $1 d$.

71. Zoller, supra note 1 , at 18.

72. See U.N. Press Rel. 3047 (27 Feb. 1992), at 2.

73. U.N. Doc. E/CN.4/1992/50 and Add.1 (1992). 
efforts to improve the situation of human rights in Haiti, but had faced many obstacles-especially the military, the security forces, and the conservative elite of the country. He also recommended that a Special Rapporteur be appointed for Haiti, and that the country be considered under the gross violations item of the agenda next year. ${ }^{74}$

In its 1992 resolution, which was adopted without a vote, the Commission strongly condemned the recent events in Haiti and expressed deep concern over the flagrant violations committed under the illegal government after the coup. These violations included summary executions, arbitrary arrests, torture, warrantless searches, rape, and political repression. ${ }^{75}$ The Commission also called on the international community to support the efforts to assist the refugees fleeing the situation in Haiti. In light of these events, the Commission acceded to Aristide's request and its expert's recommendation to significantly increase the level of scrutiny of Haiti by calling for the appointment of a Special Rapporteur to prepare a report on the human rights situation for the General Assembly and the Commission at their next meetings. The Commission álso decided to consider the situation of Haiti at its next meeting under agenda item 12 (gross violations) instead of the advisory services agenda item. ${ }^{76}$

\section{O. Iran}

In 1991, after extensive negotiations, a compromise text was agreed upon by consensus, extending the mandate of the Special Representative Galindo Pohl (El Salvador) one more year. ${ }^{77}$ The resolution also contained language to the effect that the Commission would consider the Special Representative's report with a view toward discontinuing the mandate if there was further progress achieved regarding his recommendations. ${ }^{78}$

The 1992 report of the Special Representative ${ }^{79}$ highlighted the continuing human rights violations in Iran, including the absence of fair trial guarantees, discrimination against groups of citizens (especially the Baha'is) on grounds of their religious beliefs, and the increased use of the death penalty. Concern regarding such continuing violations resulted in a new resolution that called for renewal of the Special Representative's mandate

74. See U.N. Press Release HR/3048 (27 Feb. 1992), at 3-4.

75. C.H.R. Res. 1992/77, 48 U.N. ESCOR Supp. (No.2) at 190, U.N. Doc. E/CN.4/1992/84 (1992).

76. Id.

77. C.H.R. Res. 1991/82, 47 U.N. ESCOR Supp. (No.2) at 183, U.N. Doc. E/CN.4/1991/91 (1991).

78. Id.

79. U.N. Doc. E/CN.4/1992/34 (1992). 
for another year ${ }^{80}$ Iran strenuously objected to the new resolution, arguing that it was a major departure from the previous year's resolution without any justification. At Iran's request, therefore, there was a roll call vote pursuant to which the resolution was approved twenty-two in favor, twelve against, fifteen abstaining, and four absent.

\section{P. Iraq}

In 1991, after several years of inaction regarding Iraq, the violations associated with the Persian Gulf War spurred the Commission to appoint a Special Rapporteur to study the violations of human rights by the government of Iraq, including violations of the rights of the Kurds, ${ }^{81}$ and another Special Rapporteur to study the situation of human rights in Kuwait under Iraqi occupation. ${ }^{82}$

The Special Rapporteur on Iraq, Max van der Stoel (Netherlands), issued a report detailing the massive violations of human rights by the Iraqi government, including summary and arbitrary executions, torture (including torture of children), and political repression. ${ }^{83}$ Many experienced Commission observers and participants called this hard-hitting report one of the best ever submitted to the Commission. Although the government formally cooperated with the Special Rapporteur, it did not fully or satisfactorily reply to his inquiries about the violations, and he could find no reliable indicator that the government has taken steps to prevent such violations from occurring in the future. ${ }^{84}$ In light of Iraq's grave human rights record in recent years, the Special Rapporteur recommended an exceptional measure: sending a team of human rights monitors to remain in Iraq until conditions improve for the thousands of people in jeopardy. ${ }^{85}$

The Commission's resolution condemning violations by Iraq refers to the most relevant Security Council and General Assembly resolutions regarding the human rights situation in the country, and strongly condemns the government's massive human rights violations. ${ }^{86}$ The resolution also calls upon the government to release all those arbitrarily detained and to respect

80. C.H.R. Res. 1992/67, 48 U.N. ESCOR Supp. (No.2) at 156, U.N. Doc. E/CN.4/1992/84 (1992).

81. C.H.R. Res. 1991/74, 47 U.N. ESCOR Supp. (No.2) at 167, U.N. Doc. E/CN.4/1991/91 (1991).

82. C.H.R. Res. 1991/67, 47 U.N. ESCOR Supp. (No.2) at 154, U.N. Doc. E/CN.4/1991/91 (1991).

83. See U.N. Doc. E/CN.4/1992/31 (1992).

84. $/ d$.

85. $/ d$.

86. C.H.R. Res. 1992/71, 48 U.N. ESCOR Supp. (No.2) at 166, U.N. Doc. E/CN.4/1992/84 (1992). 
the rights of all of its citizens, regardless of their origin. ${ }^{87}$ During the floor debate on the resolution, some of the references to the particular plight of the Kurds and the Shi'a communities were modified in Syrian amendments which were accepted by the cosponsors. Yet the resolution continued to call attention at key points to the particular repression aimed at these communities and the special concern of the Commission for their plight. ${ }^{88}$ Based on the seriousness of the human rights situation, the Commission also requested the Special Rapporteur, in consultation with the Secretary-General, to develop further his recommendation for an exceptional on-site response and to report on the subject to the General Assembly at its next session. ${ }^{89}$ The resolution, which passed by a large majority of thirty-five in favor, one (Iraq) against, and sixteen abstentions, also extended the mandate of the Special Rapporteur for another year. ${ }^{90}$

Regarding the human rights situation in occupied Kuwait, the report of Special Rapporteur Walter Kalin (Switzerland) emphasized the grave violations of international humanitarian law that had been perpetuated by Iraq, and the thousands of people still detained and missing, but also detailed the many other rights violated by Iraq during its occupation of Kuwait. ${ }^{91}$ The Commission's resolution tracked these two broad themes, expressing deep concern at the general human rights violations in occupied Kuwait, but focusing in its operative paragraphs on the continuing violations of humanitarian law, especially the ill-treatment, torture, and summary execution of prisoners of war and detained civilians, and the need for full information about and the release of Kuwaitis and third-country nationals still detained by Iraq or who may have died in detention. ${ }^{92}$ To that end, the resolution demanded that Iraq cooperate with organizations such as the International Committee of the Red Cross in their search for information and eventual repatriation of prisoners of war and third-country detainees. ${ }^{93}$ The resolution did not, however, continue the mandate of the Special Rapporteur on the human rights situation in Iraqi-occupied Kuwait.

Iraq made an effort at floor amendments broadening the resolution to call for information about missing Iraqis and requiring the governments of Kuwait and Saudi Arabia to cooperate with the Red Cross; this amendment was rejected by a vote of one (Iraq) in favor, twenty-eight against, and twenty abstentions. The resolution on the situation of human rights in occupied

\footnotetext{
87. Id.

88. Id.

89. $l d$.

90. $1 d$.

91. See U.N. Doc. E/CN.4/1992/26 (1992).

92. C.H.R. Res. 1992/60, 48 U.N. ESCOR Supp. (No.2) at 140, U.N. Doc. E/CN.4/1992/84 (1992).

93. Id.
} 
Kuwait was then passed by the overwhelming vote of forty-seven in favor, one (Iraq) against, and one abstention.

\section{Q. Israeli-Occupied Arab Territories}

Once again, the Commission passed several resolutions dealing with the Israeli occupation of the Arab territories it has held since 1967. Except as noted below, the resolutions did not differ materially from the resolutions adopted in 1991 and during the last several years.

One traditional resolution condemned the Israeli occupation of and conduct in the Golan heights formerly under the control of Syria. ${ }^{94}$ Another resolution (1) called on Israel to withdraw from the occupied territories, and (2) condemned Israel for its violations of the Geneva Conventions. ${ }^{95}$ Because of significant pre-Commission publicity that had greeted the deportation of certain prominent Palestinians, the second part of this resolution emphasized a bit more strongly than in previous years the call for Israel to "refrain from deporting Palestinians from their homeland." The two parts of this resolution were adopted by votes of twenty-eight and twenty-six in favor, the United States against, and ten and eleven abstentions, respectively. Still another resolution condemned the Israeli practice of continuing to encourage settlements in the occupied territories, especially in light of the Madrid Peace Process, ${ }^{96}$ but in this instance (and as in previous years), rather than oppose the resolution, the United States abstained. The resolution was thus adopted by a margin of thirty-eight in favor, and none against.

The Sub-Commission's idea of requesting an advisory opinion from the World Court on the legality of the Israeli settlements in the occupied territories was postponed until next year. ${ }^{97}$

PLO President Yasser Arafat's address to the Commission generated some controversy, when the United States delegation successfully objected to Arafat being provided head of state status (i.e., being allowed to address the Commission from the primary podium). Arafat was able to make the point, however, that the Palestinians were not allowed to designate their own representatives in the Madrid Peace negotiations.

94. C.H.R. Res. 1992/1, 48 U.N. ESCOR Supp. (No.2) at 19, U.N. Doc. E/CN.4/1992/84 (1992).

95. C.H.R. Res. 1992/2 (A and B), 48 U.N. ESCOR Supp. (No.2) at 21, 23, U.N. Doc. E/ CN.4/1992/84 (1992).

96. C.H.R. Res. 1992/3, 48 U.N. ESCOR Supp. (No.2) at 25, U.N. Doc. E/CN.4/1992/84 (1992).

97. C.H.R. Dec. 1992/104, 48 U.N. ESCOR Supp. (No.2) at 209, U.N. Doc. E/CN.4/1992/ 84 (1992). 


\section{R. Lebanon}

The Commission once again adopted its standard resolution condemning the continued Israeli violations of human rights in southern Lebanon, including arbitrary detention of members of the civilian population, destruction of homes, bombing of villages, etc. ${ }^{98}$ This year the resolution was adopted by a margin of forty-nine in favor, one (the United States) against, and one (Uruguay) abstaining. The 1992 resolution differed from the one adopted the previous year only by a reference to the new impetus given the Middle East peace process, and the hindrance to that process presented by Israel's activities in southern Lebanon.

\section{S. Myanmar (Burma)}

If China was the exception to the general progress that was made during the 1992 Commission, Myanmar (Burma) was representative of what it is hoped will become the new "rule" for Commission proceedings. For the last several years, Myanmar had been considered under the 1503 confidential procedure, pursuant to which an independent Expert had been given a mandate to pursue direct contacts with the Myanmar government and to report to the Commission at its next session. ${ }^{99}$

The question of Myanmar gained momentum last year, when the leading opponent of the government Daw Aung San Suu Kyi won the Nobel Peace Prize. France took the lead at the 1992 Commission in bringing Myanmar out of the confidential procedure into public proceedings, and must be credited with securing the large number of sponsors from diverse regions for its public resolution. The resolution itself "deplores" the fact that despite commitments to the contrary, the government of Myanmar has stifled the democratic process by refusing to give effect to the will of the electorate as expressed in the 1990 elections. ${ }^{100}$ It also expresses concern at the continued detention of political prisoners and the conditions leading to the exodus of Myanmar refugees, and decides to appoint a Special Rapporteur to examine the situation and report back to the Commission and to the General Assembly. ${ }^{101}$ Myanmar's primary response, reminiscent of that of China, was to invoke the ancient and increasingly anachronistic argument that the Commission was interfering in matters wholly within the domestic jurisdiction of Myanmar.

98. C.H.R. 1992/70, 48 U.N. ESCOR Supp. (No.2) at 165, U.N. Doc. E/CN.4/1992/84 (1992).

99. Parker \& Weissbrodt, supra note 1, at 590.

100. C.H.R. Res. 1992/58, 48 U.N. ESCOR Supp. (No.2) at 136, U.N. Doc. E/CN.4/1992/84 (1992).

101. Id. 
Significantly, the resolution on Myanmar had sponsors from every regional grouping within the United Nations, and was adopted without the need for a vote by the Commission. The Myanmar resolution thus illustrates the Commission's new potential, in this era of pragmatism, for more cooperative action on serious human rights situations of general concern.

\section{T. Romania}

In the case of Romania, the Commission decided to ease its scrutiny of the human rights situation by allowing the mandate of the Special Rapporteur, Joseph Voyame (Switzerland) to expire, but by requesting the SecretaryGeneral to present a report to the Commission at its 1993 meeting regarding the Romania government's implementation of the Commission's resolution.

The 1992 report of the Special Rapporteur noted that the human rights situation in Romania still continued to improve, especially with respect to new laws incorporating international human rights standards, but that significant issues remained. ${ }^{102}$ These issues include the problems of effectively applying the new laws, in light of limited resources and some residual attitudes (and in some cases, personnel) from the Ceaucescu regime, problems of maintaining the impartiality of the justice system, and problems of fair treatment of minorities. ${ }^{103}$ The resolution noted these continuing issues and urged the government of Romania to implement the recommendations of the Special Rapporteur. ${ }^{104}$ In addition, the resolution thanked the Special Rapporteur for his efforts, and established the monitoring mechanism under the Secretary-General mentioned above. ${ }^{105}$

\section{U. Somalia}

The situation of human rights in Somalia was once again considered by the Commission in confidential 1503 proceedings. Apparently, there was no response from the Somalian government, so the Commission determined by consensus to keep the country under review for another year. The situation in Somalia was reportedly perceived as so grave, however, that the Commission decided to request the Secretary-General or his designee to contact the government directly to try to clarify the situation.

102. See U.N. Doc. E/CN.4/1992/28 (1992).

103. Id.

104. C.H.R. Res. 1992/64, 48 U.N. ESCOR Supp. (No.2) at 150, U.N. Doc. E/CN.4/1992/84 (1992).

105. Id. 


\section{South Africa}

The changes in the human rights situation in South Africa in the year prior to the 1992 Commission were among the most dramatic seen by the Commission. South Africa repealed major pieces of apartheid legislation, including the Group Areas Act, the Population Registration Act, the Land Acts of 1913 and 1936, and portions of the Internal Security Act that provided for indefinite incommunicado detention. The government also took initiatives to reduce the political violence, with the National Peace Accord, and to begin broad-based negotiations aimed at genuine power sharing, through the Convention of a Democratic South Africa. The precursor to these changes the previous year, including the repeal of portions of the Reservation of Separate Amenities Act, had enabled the Commission for the first time to adopt its basic resolution on South Africa by consensus. ${ }^{106}$ The resolution in 1992 was also adopted without a vote.

The most significant changes from the previous year in the text of the primary South African resolution emphasized the positive developments taking place. Nonetheless, the resolution emphasized that much remains to be done, including abolition of the bantustans ("homelands"), repeal of remaining apartheid legislation, reduction of the political violence, elimination of any involvement of the security forces in the violence, elimination of the arbitrary detention and ill-treatment in detention of children, and a new Constitution that provides for genuine power sharing with the majority of the population. ${ }^{107}$ While the Commission reiterated the conviction that international pressure has had a major influence on positive developments, and continues to be necessary, the resolution also calls for a "flexible" strategy "through the phased application of appropriate pressures and for needed assistance and encouragement to the parties concerned." ${ }^{108}$ Perhaps as one example of this flexibility, the Commission welcomed "the international consensus to lift restrictions on people-to-people contacts and cultural and scientific links with South Africa in recognition of the progress made so far towards the dismantling of apartheid."109 The resolution also renewed the request that the Ad Hoc Working Group on South Africa be allowed to visit the country, which is now a more realistic possibility. ${ }^{110}$

On the topic of the adverse consequences of assistance to the South

106. C.H.R. Res. 1991/21, 47 U.N. ESCOR Supp. (No.2) at 60, U.N. Doc. E/CN.4/1991/91 (1991).

107. C.H.R. Res. 1992/19, 48 U.N. ESCOR Supp. (No.2) at 60, U.N. Doc. E/CN.4/1992/84 (1992).

108. Id.

109. Id.

110. Id. 
African regime, the Commission had before it the update report of the SubCommission's Special Rapporteur (Ahmad Khalifa-Egypt) on corporations doing business in South Africa. ${ }^{11}$ The Commission again expressed its conviction that sanctions have played a great role in bringing about change in South Africa, and remain an effective instrument of pressure. In the 1992 resolution, however, which was adopted by a vote of thirty-five in favor, fifteen against, and three abstentions, the rhetoric regarding the "complicity in the crime of apartheid" by transnational corporations that collaborate with the South African government was toned down slightly, and there were new paragraphs looking toward a post-apartheid order by calling for humanitarian and legal assistance to the victims of apartheid and to returning political exiles and refugees. ${ }^{12}$ The resolution also contained a new call for South Africa to allow a visit by Special Rapporteur Khalifa, which now is at least conceivable. ${ }^{113}$ The resolution, as in previous years, also called for governments to continue sanctions against South Africa until agreement has been reached for a new constitution and elections. ${ }^{114}$ By a similar roll-call vote of thirty-three in favor, fourteen against, and five abstentions, the Commission also adopted its standard resolution calling for the Special Rapporteur to update his report on corporations, banks, and other organizations assisting South Africa. ${ }^{15}$

\section{W. Sri Lanka}

Sri Lanka was the object of much attention during the Commission. A number of NGOs during the debate on the self-determination item raised the issue of Sri Lankan denial of the rights of the Tamil people to self-determination. Both governments and NGOs were critical of the fact that the overwhelming majority of the disappearances which the Working Group on Enforced and Involuntary Disappearances transmitted to governments in the previous year involved Sri Lanka. The problem of impunity for human rights violators in Sri Lanka was also a theme of many interventions of governments and NGOs. The violations and the problems of impunity resulted in a number of calls for the Commission to appoint a Special Rapporteur for Sri Lanka. The statement of Sandra Coliver of the human rights organization Article 19/

111. U.N. Doc. E/CN.4/Sub.2/1991/13 and Add.1.

112. C.H.R. Res. 1992/20, 48 U.N. ESCOR Supp. (No.2) at 64, U.N. Doc. E/CN.4/1992/84 (1992).

113. Id.

114. Id.

115. C.H.R. Res. 1992/7, 48 U.N. ESCOR Supp. (No.2) at 33, U.N. Doc. E/CN.4/1992/84 (1992). 
International Centre Against Censorship was a prominent example of such an intervention. ${ }^{16}$

The Sri Lanka government expressed what many were persuaded was genuine concern about human rights violations in its territory; the Commission wanted to encourage this attitude and the willingness of the Sri Lankan government to take steps to prevent recurrences. In his introduction to the report of the Working Group on Enforced and Involuntary Disappearances, the Chair of the Working Group praised the cooperation of the Sri Lankan government, as did a number of governments speaking in reaction to the report (e.g., Australia, the United Kingdom).

In his comments on the report and generally on the human rights situation in Sri Lanka, the representative of Sri Lanka thanked the Working Group for its report, stated that at points the Working Group failed to fully appreciate the complex historical, economic, and social factors underlying the conflicts in the south and north. The representative stated that the conflict in the south was essentially over, and the violations in the north, though perhaps slightly overstated, were certainly deplorable. The representative concluded by stating that many of the recommendations of the Working Group and of Amnesty International (including 30 of the 32 Amnesty recommendations) were already being implemented, and that the others were being studied and would be implemented wherever possible. Sri Lanka also expressed willingness to receive a follow-up visit of the Working Group on Disappearances as well as the Special Rapporteur on Summary or Arbitrary Executions. A Presidential Commission had been established to investigate disappearances alleged to have occurred after January 1991, a new task force had been created to monitor treatment of detainees, and another Presidential Commission had been established to investigate allegations of indiscriminate shootings. ${ }^{17}$

This cooperative attitude convinced the Commission to refrain from making any condemnation or elevating its scrutiny of Sri Lanka, either through adopting a resolution or appointing an expert or Special Rapporteur. Instead, as in the case of East Timor, the Commission authorized a consensus statement acknowledging the steps taken by Sri Lanka to address the human rights situation in the country, welcoming the cooperation shown with the Working Group on Disappearances, but expressing serious concern over the human rights situation. While the statement will appear in the record of the proceedings, it will not appear in the list of resolutions and decisions. The statement concludes by calling for the Sri Lankan government to continue

116. Statement of Sandra Coliver on 20 February 1992, U.N. Press Release HR/3038 (20 Feb. 1992)(describing the mass and flagrant human rights violations in Sri Lanka and calling for the appointment of a Special Rapporteur).

117. Ambassador Kenneth Blackwell, statement at press conference on 6 March 1992, Geneva, Switzerland. 
to implement human rights reforms and the recommendations of the Working Group. ${ }^{118}$

A number of representatives of NGOs were disappointed with a consensus statement rather than the appointment of a Special Rapporteur, and viewed this outcome as a failure. ${ }^{19}$

\section{Sudan}

In 1991, the situation in human rights in Sudan was the subject of a communication under the confidential 1503 procedure. In 1992, there was significant pressure to transfer consideration of the situation in Sudan to the Commission's public procedures. Instead, at the urging of the United States, the level of scrutiny was raised a notch through the naming of an independent expert to report on the human rights situation in the Sudan (still in the context of the confidential procedure). The increased scrutiny was reportedly adopted by a vote of twenty-seven in favor, and seven (China, Cuba, Iran, Iraq, Libya, Nigeria, and Pakistan) against, with sixteen abstentions.

\section{Y. Western Sahara}

For the third year in a row, the Commission adopted by consensus a resolution on the self-determination of the people of the Western Sahara. ${ }^{120}$ This year's resolution took note of the Security Council's decision to establish a United Nations Mission for the Referendum in Western Sahara, welcomed the entry into force of the fall 1991 cease-fire in accordance with the proposals of the Secretary-General, and expressed full support for the efforts of the Secretary-General and the Organization of African Unity toward peace in the Western Sahara.

\section{Z. Zaire}

The Commission decided last year to drop consideration of Zaire, despite evidence of continued gross violations of human rights in the country. The serious allegations of human rights violations in Zaire, however, were the subject of a new communication under the confidential 1503 procedure.

118. See U.N. Press Rel. HR/3048 (27 Feb. 1992).

119. See, e.g., Zoller, supra note 1 , at 23.

120. C.H.R. Res. 1992/18, 48 U.N. ESCOR Supp. (No.2) at 58, U.N. Doc. E/CN.4/1992/84 (1992). 
The Commission thus reportedly decided by consensus not only to keep Zaire under consideration for another year, but to appoint a new expert to study and report on the situation there.

The "massacre at Lubumbashi" in Zaire was also the subject of a separate report ${ }^{121}$ by the Special Rapporteur on summary and arbitrary executions, which is further reviewed under "executions" in connection with the discussion of the thematic mechanisms below. Zaire was also mentioned in other thematic reports on mercenaries and torture.

\section{AA. Other Situations Not Considered}

As usual, there were a number of country situations regarding which, for a variety of reasons, the Commission failed even to consider action. Abundant evidence, including that gathered by the Commission's own thematic procedures, continued to point to serious violations in countries such as Brazil, Colombia, Ethiopia, Peru, the Philippines, Turkey, and Viet Nam. NGOs also commented on such situations as the plight of refugees in Hong Kong and the use of torture in India. Yet the Commission took no action regarding these situations.

\section{THEMATIC MECHANISMS}

Since the Working Group on Enforced or Involuntary Disappearances was created by the Commission in 1980, such thematic mechanisms have become the most effective and objective human rights monitoring bodies of the international community. The thematic mechanisms focus on specific types or categories of human rights violations. Currently, there are seven thematic mechanisms of the Commission. In addition to the Working Group on Disappearances, there is a new Working Group on Arbitrary Detention (which was established at the 1991 session of the Commission), and there are special rapporteurs on executions, torture, religious intolerance, mercenaries, and children. Even if the Commission does not take action with respect to a certain country, the thematic mechanisms often provide important information about human rights violations in that country.

\section{A. Disappearances}

The original thematic mechanism of the Commission, the Working Group on Enforced or Involuntary Disappearances, is also generally considered the

121. U.N. Doc. E/CN.4/1992/30/Add.1 (1992). 
most effective of the Commission's theme mechanisms. Its working methods are action-oriented: the Working Group maintains a computerized database of disappearances, transmits cases to the governments concerned, transmits governmental replies to interested relatives, pursues further follow-up and dialogue regarding cases, takes urgent action in a number of cases, and is the only thematic mechanism that routinely invites the authors of complaints to comment upon the official responses of governments so as to evaluate those responses. The Working Group has been "the cornerstone of international efforts to help relatives in their search for the victims of disappearances and in working to prevent future disappearances." ${ }^{122}$ This action orientation of the Working Group leads it to serve as a model for the other thematic procedures.

Since 1980, the Working Group has now transmitted almost 25,000 cases of disappearance relating to forty-seven countries. ${ }^{123}$ In 1991, the Working Group received 17,000 reports of disappearances. ${ }^{124}$ Of these, 4,800 newly reported cases were transmitted to twenty-five governments, 636 of which were said to have occurred in $1991 . .^{125}$ The urgent action procedure was used in 330 of the cases, resulting in clarification of thirtyfour cases during the year. ${ }^{126}$

Peru was finally displaced as the world leader in number of disappearances alleged to have occurred annually, as Iraq had 342 cases reported to have occurred in 1991, ${ }^{127}$ whereas Peru had $117 .{ }^{128}$ The number in most other countries generally decreased in 1991, although a significant number of cases continued to be reported in Colombia (twenty), El Salvador (thirty), and Guatemala (thirty), for example. Sri Lanka had forty-one cases reported to have occurred in 1991, and the number of reported cases in the Philippines, the subject of a special visit from the Working Group in 1991, declined from forty-seven in 1990 to five in 1991.

The Working Group's report, introduced by Ivan Tosevski (Yugoslavia), reflected an "unexpected resurgence" of the problem in some countries. ${ }^{129}$ Of the 4,800 total cases of disappearances processed and transmitted to governments during 1991, 3,841 were sent to the government of Sri Lanka. ${ }^{130}$ In addition to the regular report of the Working Group, the Commission had before it the report of the visit to Sri Lanka by three members of the Working

122. Parker \& Weissbrodt, supra note 1, at 594-95.

123. U.N. Doc. E/CN.4/1992/18 (1992), at 90.

124. Id. at 5 .

125. $/ d$.

126. $/ d$.

127. Id. at 53

128. Id. at 72

129. Id. at 1 .

130. Id. 
Group from 7 to 18 October 1991. ${ }^{131}$ The report on the visit to Sri Lanka noted that the government had cooperated not only with the Working Group, but also with international human rights groups that had been allowed to visit Sri Lanka during the year. ${ }^{132}$ According to the analysis of the Working Group, the adverse human rights situation in Sri Lanka has its roots in the government's conflict with the Tamil separatist militants in the north, and the conflict with the People's Liberation Front (JVP) in the south. As the Working Group has pointed out with respect to a number of other country situations, such conflicts are heavily influenced by both socioeconomic as well as political factors, including the increasing poverty and the breakdown of political processes in Sri Lanka. ${ }^{133}$ And although a state may have a right to use force in certain circumstances, the report continues, there are international human rights norms placing limits on the use of such force, especially against noncombatant civilians. Nonetheless, more than 12,000 cases of disappearance in Sri Lanka have been recorded by the Working Group since 1983. ${ }^{134}$

The situation in Sri Lanka exemplifies two of the prime factors resulting in disappearances. The most important factor contributing to the problem of disappearances continued to be "impunity"135 - the lack of accountability of certain human rights violators. In the Sri Lankan case, for example, there is repressive security legislation which contributes to a climate of impunity; the government stated that all methods were legitimate in dealing with terrorists, and an Indemnity Act was passed excusing a number of violators from certain crimes. ${ }^{136}$ The report of the Working Group also reiterated that disappearances have occurred primarily in situations of social tension or armed conflict. ${ }^{137}$ Discouraging impunity and resolving armed conflict would go far toward reducing cases of disappearances, in Sri Lanka and elsewhere.

In its consensus resolution on the question of enforced disappearances, the Commission commended the Working Group on its report, urged governments to cooperate with the Working Group and to take measures to punish those responsible for disappearances, and extended the mandate of the Working Group for three years. ${ }^{138}$ The Commission also considered the report of the Sub-Commission's Working Group on Detention, which had

131. U.N. Doc. E/CN.4/1992/18/Add.1 (1992). This report was highly praised by a number of knowledgeable sources, including Zoller, supra note 1 , at 7 , who stated that it is "one of the best reports ever produced at the United Nations on the analysis of violations and their causes in a given country."

132. U.N. Doc. E/CN.4/1992/18/Add.1 (1992), at 35.

133. Id. at 36 .

134. Id. at $36-37$.

135. U.N. Doc. E/CN.4/1992/18 (1992), at 2.

136. See U.N. Doc. E/CN.4/1991/18/Add.1 (1991), at 39.

137. Id. at 90 .

138. C.H.R. Res. 1992/30, 48 U.N. ESCOR Supp. (No.2) at 81, U.N. Doc. E/CN.4/1992/84 (1992). 
been charged with producing a Draft Declaration on the protection of all persons from enforced disappearances, ${ }^{139}$ and adopted a resolution approving the Draft Declaration (which is further discussed in Section VIII. C., below). ${ }^{140}$

\section{B. Executions}

The first decade (1982-1992) of activity by the Special Rapporteur for summary or arbitrary executions, Amos Wako (Kenya), has seen significant evolutions of his mandate. ${ }^{141}$ Beginning in 1985, an urgent action procedure was implemented not only for cases of persons in custody where there was reason to believe that execution was imminent, but also for death threats or situations where excessive force used by security forces might be repeated. ${ }^{142}$ One of the main contexts in which questions arise as to whether an execution might be summary or arbitrary is the death penalty, and the Special Rapporteur has sent many urgent actions attempting to ensure that the safeguards of Article 14 of the Covenant on Civil and Political Rights are implemented in such situations. ${ }^{143}$ The Special Rapporteur has interpreted his mandate to extend not only to cases where a government official was actually involved in an arbitrary execution, but also where the killing was committed with the "complicity, tolerance, or acquiescence" of a government. ${ }^{144}$ Executions by opposition forces and by drug traffickers are also within the mandate of the Special Rapporteur. ${ }^{145}$

Throughout the decade, the number of cases handled by the Special Rapporteur has grown tremendously, and now that number is among the largest of the thematic procedures. In the sixth year of the mandate, for example, 100 communications regarding executions were sent to forty-six countries. In 1991, 174 communications were sent to sixty-five countries, including both urgent appeals and requests for information concerning allegations. ${ }^{146}$ In addition, in connection with his mandate to send urgent appeals in cases where individuals or groups are allegedly subject to reprisals or intimidation for seeking to cooperate with the United Nations or for availing themselves of its human rights procedures, the Special Rapporteur sent urgent appeals to forty-nine governments concerning some 4,200 cases

139. U.N. Doc. E/CN.4/1992/19/Rev.1 (1992).

140. C.H.R. Res. 1992/29, 48 U.N. ESCOR Supp. (No.2) at 80, U.N. Doc. E/CN.4/1992/84 (1992).

141. U.N. Doc. E/CN.4/1992/30 (1992), at 161.

142. Id.

143. Id. at 162.

144. Id.

145. Id. at 164 .

146. Id. 
of death threats. ${ }^{147}$ While the Special Rapporteur reports that most governments have been cooperative at least in the sense of replying in some fashion to his communications (although the replies do not always reveal a sincere intention to take measures to combat arbitrary executions), a number of countries persist in refusing any cooperation. These uncooperative countries are Chad, Haiti, Libya, Pakistan, Somalia, South Africa, Thailand, Uganda, and Zaire. ${ }^{148}$

At the invitation of the government of Zaire, the Special Rapporteur undertook a visit to Zaire in 1991, to investigate the trial in the matter of State $v$. Koyagialo, concerning the events that transpired at the campus of Lubumbashi during the period 8-12 May 1990. A separate document before the Commission contained the report of the visit. ${ }^{149}$ A group of "commandos" had attacked students on the campus shortly after a group of student activists had conducted a "people's court" against several government informers. Thirty-four students were wounded in the reprisal, and at least ten to twelve students were killed; the campus was gutted. After a number of personal meetings and analysis of investigative findings, the Special Rapporteur concluded that the government of Zaire ordered or authorized the operation of two attack groups in connection with the incident. ${ }^{150}$ Accordingly, the Special Rapporteur called to the attention of the government of Zaire its responsibilities under the relevant international human rights instruments and codes of conduct for law enforcement officials. The Special Rapporteur concluded that the judgment in the Koyagialo case did not fully discharge the obligation of the government under such standards, due to the fact that only seven individuals were convicted for their involvement in the incident, there were other missing defendants, and factual issues remained to be resolved. Hence, the Special Rapporteur requested that the government reopen its investigation and communicate the results to him. ${ }^{151}$

In his general recommendations to governments and the international community after a decade of monitoring summary and arbitrary executions, the Special Rapporteur reiterated the need to respond rapidly and effectively to situations of internal armed conflict and civil strife-the major cause of such executions. ${ }^{152}$ Most of his recommendations emphasized the need to ratify and implement international human rights standards regarding protection of the right to life, and training for law enforcement, judicial, correctional, and military personnel regarding such standards. In addition, he recommended concerted, long-term efforts at eliminating the root causes of

147. Id. at 166.

148. Id. at 170 .

149. U.N. Doc. E/CN.4/1992/30/Add.1 (1992).

150. Id. at 91 .

151. Id. at 93.

152. U.N. Doc. E/CN.4/1992/30 (1992), at 174. 
violence and intolerance, "in particular economic injustice, totalitarian political ideologies, and racial, national, ethnic and religious prejudice." ${ }^{153}$

The Commission's resolution on summary executions, adopted by consensus, once again condemns the large number of summary executions taking place. Because Mr. Wako will be resigning as Special Rapporteur (to serve as Attorney General of Kenya), the resolution also thanks him for the manner in which he discharged his duties, and calls for the Commission's Chair to appoint a new Special Rapporteur for a three-year term. ${ }^{154}$ The new Special Rapporteur will be Bacre W. Ndiaye (Senegal).

\section{Torture}

The Special Rapporteur on torture, Peter Kooijmans (Netherlands), presented his seventh report to the Commission. The report continued to summarize the most relevant aspects of his correspondence with various governments regarding alleged incidents of torture, as well as aspects of the governments' replies. This methodology enhances the accuracy of the allegations and responses, while encouraging thoughtful responses (and indicating to some degree the seriousness with which governments take their responsibilities to prevent torture).

As is the case with the Working Group on Disappearances and the Special Rapporteur on summary or arbitrary executions, the mandate of the Special Rapporteur on torture also includes an urgent action capability. Urgent actions are sent in cases of ongoing or imminent torture (e.g., in situations of incommunicado detention), and are primarily intended to give governments the opportunity to investigate situations and to instruct detaining authorities to respect the physical and mental integrity of detainees. In 1991, the Special Rapporteur sent 64 urgent messages, each relating to one or more persons, to the respective governments. ${ }^{155}$ The Special Rapporteur also noted in presenting his report that he had sent ten urgent actions since the report was completed. ${ }^{156}$

The Special Rapporteur reiterated his recommendations that incommunicado detention be made illegal, and that places of detention should be routinely inspected by independent experts. ${ }^{157}$ This latter recommendation stems from the system of periodic visits to detention facilities of the

153. Id. at 173.

154. C.H.R. Res. 1992/72, 48 U.N. ESCOR Supp. (No.2) at 169, U.N. Doc. E/CN.4/1992/84 (1992).

155. U.N. Doc. E/CN.4/1992/17 (1992), at 6.

156. The Special Rapporteur mentioned that these urgent actions were sent, inter alia, to the governments of Cameroon, China, Egypt, Haiti, and Syria.

157. U.N. Doc. E/CN.4/1992/17 (1992), at 106. 
sort instituted by the Council of Europe, and the Special Rapporteur believes that such a mechanism would be an effective preventive measure against the use of torture. ${ }^{158}$ The proposal by Costa Rica for an Optional Protocol to the Convention Against Torture would be a worldwide system along these lines. More generally, the Special Rapporteur reiterated the need to implement on a national level the rules adopted on the international level..$^{159}$ Training for the judiciary and for law enforcement and security personnel should emphasize the need to enforce norms against torture. ${ }^{160}$ Victims of torture should be compensated without delay and the perpetuators severely punished. ${ }^{161}$ In Kooijmans' remarks introducing his report, the Special Rapporteur noted that some of his recommendations from 1990 had been implemented by the government of Guatemala two weeks previously, and that this positive development would be reflected in next year's report.

During the year, the Special Rapporteur visited Indonesia and East Timor. The visit took place from 4 to 16 November $1991 .{ }^{162}$ Some of the leading human rights activists that met with the Special Rapporteur emphasized the widespread denials of the fundamental rights of freedom of expression and association, and the causal connection between denials of these rights and other human rights violations in Indonesia. ${ }^{163}$ An important aspect of the visit was the opportunity to meet with several of the detainees who had been the subject of communications from the Special Rapporteur. In Cipinang prison, for example, the Special Rapporteur met privately with several such prisoners, all except one of whom confirmed that during their prior interrogation by the military, they had been tortured (although they were being treated humanely in Cipinang prison itself). ${ }^{164}$ The Special Rapporteur reviewed in detail the Indonesian legal system and its absence of true safeguards (e.g., judicial review of complaints against police in cases of alleged illtreatment of prisoners). Unfortunately, the Chief Justice of the Supreme Court declined a meeting with the Special Rapporteur on the grounds that the executive branch could provide any information needed. This action confirmed the impression of the Special Rapporteur that the Indonesian judiciary is not sufficiently aware of the important role it can and should play in eradicating the practice of torture in Indonesia. ${ }^{165}$

The tragic events in East Timor on 12 November happened to take place during the Special Rapporteur's visit to the region. Although the events did

158. Id. at 104-05. This point was also highlighted by the Special Rapporteur in his statement on the floor introducing the report. See U.N. Press Release HR/3025 (11 Feb. 1992).

159. U.N. Doc. E/CN.4/1992/17 (1992), at 104-105.

160. Id. at 107.

161. Id. at 106.

162. U.N. Doc. E/CN.4/1992/17/Add.1 (1992), at 2.

163. Id. at 3.

164. Id.

165. Id. at 10 . 
not, strictly speaking, fall within his mandate, as a representative of the United Nations Commission who was a short distance from the scene, he felt obligated to describe "what he saw and heard." memorial ceremony for the victims of an earlier incident (on 28 October) during which two lives were lost. At the ceremony, flags of Portugal and Fretilin (Frente Revolucionaria de Timor Leste Independente) were unfurled. Security troops opened fire and a great number of people were killed or injured. While not an eyewitness to this event, and despite differing versions of what sparked the shooting, the Special Rapporteur did have follow-up meetings with various officials in an attempt to ensure that those who had been detained would be treated humanely, and attempted to visit the hospital where dozens of the wounded from the incident were being treated. His request was denied, however, on the grounds that such a visit could be interpreted as United Nations endorsement of the opposition forces, and could lead to more rioting. ${ }^{167}$

The Special Rapporteur could not avoid the conclusion that torture did occur relatively frequently in Indonesia, especially in East Timor. In addition to ratifying the relevant international instruments, his most significant recommendations were that the Indonesian government respect guarantees of access to lawyers, dismiss evidence not obtained in conformity with law, repeal the "Anti-Subversion Law," establish a national commission on human rights as well as an agency independent of the police where victims of human rights violations can file complaints, severely punish officials who have been found guilty of violations, and give jurisdiction of offenses by members of the police and armed forces to civilian courts. ${ }^{168}$

The resolution on renewing the mandate of the Special Rapporteur on torture (as well as the resolutions on renewing the mandates of the other special rapporteurs, especially the Special Rapporteur on religious intolerance), gave the Commission occasion to debate the general circumstances under which, and the periods of time for which, the mandates of such special rapporteurs should be renewed. ${ }^{169}$ There was some sentiment that, in light of the limited resources of the United Nations in general and the Commission in particular, renewal of such mandates should not be automatic, but should be carefully scrutinized on a case-by-case basis. Other nations argued that the principle of granting mandates to the thematic mechanisms for three years, which had been debated at previous Commission sessions and accepted by ECOSOC as standard operating procedure, ${ }^{170}$ was an essential

166. Id. at 12 .

167. Id. at 15 .

168. Id. at 20-21.

169. See generally U.N. Press Release HR/3050 (28 Feb. 1992).

170. E.S.C. Res. 1990/48, U.N. Doc. E/1990/INF/6 (1990), at 80. 
guarantee of focus, thoroughness, expertise, and independence of the thematic mechanisms.

In the specific case of the Special Rapporteur on torture, a resolution introduced by Belgium pursuant to which the mandate would be renewed for three years was opposed by the Philippines in comments that were applied not just to the Special Rapporteur on torture, but also to the other thematic mechanisms. The representative from the Philippines objected that the purpose for creating the Committee against Torture was to see that the Convention Against Torture was implemented, and argued that the presence of the Special Rapporteur was somewhat duplicative, "especially since the Centre for Human Rights can do the same job." Therefore, in addition to reserving its position on the issue of whether to extend the mandate, the Philippines suggested that at the very least the period of extension should be reviewed, and only one year was justified in the case of the Rapporteur on Torture, "so that he may wind up his mandate." The Philippines' position regarding the one-year limit on extensions was supported by China, Cuba, India, Indonesia, Iran, Nigeria, and Pakistan (all governments that had been highlighted in the report of the Special Rapporteur). Those speaking out strongly in favor of three-year renewal included Canada, Japan, Peru, Portugal, Russia, Senegal, and the United Kingdom. After some further debate over relatively minor linguistic changes, including changing "immediately" to "promptly" in the description of a detainee's rights to initiate court proceedings after detention (in order to accommodate differences in local law), the resolution including the three-year renewal was adopted without a vote. ${ }^{171}$

In related resolutions, the Commission invited states that had not already done so to ratify the Convention Against Torture, ${ }^{172}$ and to contribute to the Voluntary Fund for Victims of Torture. ${ }^{173}$

\section{Mercenaries}

The Commission had before it the fifth annual report of the Special Rapporteur on mercenaries, Enrique Bernales Ballesteros (Peru). The mandate of the Special Rapporteur in this area is to consider the use of mercenaries as a means of violating human rights and impeding the exercise of the right of

171. C.H.R. Res. 1992/32, 48 U.N. ESCOR Supp. (No.2) at 85, U.N. Doc. E/CN.4/1992/84 (1992). Although the governments opposing the three-year extension of the Special Rapporteur's mandate reportedly denied prior coordination on the issue, it was rumored that the Indonesian delegation was behind the opposition because of the Special Rapporteur's focus on Indonesia/East Timor in his report. See Zoller, supra note 1, at 10.

172. C.H.R. Res. 1992/25, 48 U.N. ESCOR Supp. (No.2) at 73, U.N. Doc. E/CN.4/1992/84 (1992).

173. C.H.R. Res. 1992/27, 48 U.N. ESCOR Supp. (No.2) at 77, U.N. Doc. E/CN.4/1992/84 (1991). 
peoples to self-determination. In addition, the Special Rapporteur continued to pay particular attention to human rights problems stemming from the activities of irregular armed groups and drug traffickers, in accordance with the Commission's resolutions applicable to all special rapporteurs and working groups.

In his report, the Special Rapporteur details the replies he received from member states in response to his correspondence inquiring about the activities of mercenaries and the status of ratification of the International Convention Against the Recruitment, Use, Financing and Training of Mercenaries. The Special Rapporteur noted information received on certain mercenary activity in internal conflicts, including French nationals in Myanmar, Israeli nationals in Sri Lanka, and Jack Terrell (a US national) in the Philippines. ${ }^{174}$ The Special Rapporteur also listed the use of mercenaries of Israeli, British, Australian, and other nationalities to provide military instruction to a Colombian group operating in the Magdalena Medio area and armed by a drug cartel, and to train assault squads of Colombian drug traffickers, as well as the use of mercenaries of South African nationality by the government of Zaire against political opponents and student groups. ${ }^{175}$

Discussing in more detail the use of mercenaries in Africa, the Special Rapporteur traced the historical use of mercenaries by the South African government in pursuit of what it perceived as its strategic interests, and reported that mercenaries are still being used by some of the vigilante racist movements violently resisting the process of negotiation and detente currently in South Africa. ${ }^{176}$ Nonetheless, the Special Rapporteur noted that "the conclusion of peace and cease-fire agreements in southern Africa is having the effect of reducing the number of mercenaries in the region." ${ }^{177}$ The peace accords signed in 1991 in Angola are one example, and the progress made in South Africa provides another. Against this progress one must set the continued repression, including the use of mercenaries, by the government of Zaire, and the continued involvement of mercenaries in Mozambique, and reportedly in Guinea and Liberia. ${ }^{178}$

With respect to Central America, the Special Rapporteur reported that he had received no further reports of mercenary activities in Central America (despite the persistence in some cases of internal armed conflict). In fact, the government of Nicaragua noted that the causes that gave rise to its previous charges that mercenaries were being used to destabilize its government had ceased to exist, and therefore it was withdrawing its request to the Special Rapporteur to investigate the charges. ${ }^{179}$

174. U.N. Doc. E/CN.4/1992/12 (1992), at 13.

175. Id. at 15.

176. Id. at 16-17.

177. Id. at 17 .

178. Id. at $26,45-48$.

179. Id. at 38 . 
The Special Rapporteur continued to urge prompt ratification of the new international Convention against Mercenaries. To date, only eighteen states have signed the Convention, of which only four have completed the process of ratification or accession. ${ }^{180}$ Since the Convention will not enter into force until thirty days after the twenty-second instrument of ratification or accession is deposited with the Secretary-General, the Special Rapporteur expressed his opinion that "the slowness of the process . . . is clearly hindering enjoyment by the international community of the safeguards established by the Convention." 181 The Special Rapporteur also recommended once again that governments criminalize the act of recruiting mercenaries, enact legislation against such activities, and cooperate with the extradition efforts of other countries. ${ }^{182}$

The Commission once again adopted without a vote its resolution expressing appreciation to the Special Rapporteur for his report, and calling on countries to accede to the new Convention against Mercenaries. In the same resolution, the Commission decided to extend the mandate of the Special Rapporteur for three years. ${ }^{183}$

\section{E. Religious Intolerance}

The Special Rapporteur on Religious Intolerance, Angelo Vidal d'Almeida Ribeiro (Portugal) presented his sixth annual report to the Commission. ${ }^{184}$ In July 1990, the Special Rapporteur disseminated a general questionnaire regarding the policies and practices of countries in the field of tolerance of religious belief. The questionnaire inquired about different treatment of religious and nonreligious institutions, believers versus nonbelievers, the treatment of conscientious objectors, the existence of protective legislation, and other subjects. The answers that were received prior to the finalization of last year's report (i.e., by 20 December 1990) ${ }^{185}$ were included in that report; ${ }^{186}$ the new report includes all of the responses received before 30 November 1991. ${ }^{187}$

180. Id. at 40 .

181. Id.

182. Id. at 47.

183. C.H.R. Res. 1992/6, 48 U.N. ESCOR Supp. (No.2) at 31, U.N. Doc. E/CN.4/1992/84 (1992).

184. U.N. Doc. E/CN.4/1992/52 (1992).

185. Id. at 89.

186. U.N. Doc. E/CN.4/1991/56 (1991).

187. U.N. Doc. E/CN.4/1992/52 (1992), at 89-90. The new replies to the questionnaire were received from the governments of Australia, Belize, Bolivia, Botswana, Burkina Faso, Canada, Cyprus, Egypt, Guinea, Haiti, Iceland, Ireland, Iran, Israel, Luxembourg, Panama, Portugal, Rwanda, Sudan, Syria, Trinidad and Tobago, Turkey, Ukraine, United States, and Zimbabwe. 
The latest report also contains a comprehensive analysis of all of the replies received to date (e.g., noting that China and Viet Nam reportedly prosecute the mere expression of religious beliefs in certain circumstances, while Iran, Iraq, and Saudi Arabia penalize the public expression of beliefs in religions other than the official religion). ${ }^{188}$ Read together, last year's report and this year's report provide invaluable information on the existing legal protections against religious intolerance, and the attitudes of individual governments including the number of governmental replies that unrealistically denied the presence of religious conflict or intolerance in their countries.

In addition to the generalized questionnaire, the Special Rapporteur sent specific communications to governments regarding situations that came to his attention and appeared to involve departures from international norms. Eight countries responded to the Special Rapporteur's request for information regarding specific incidents in their countries, and the substance of the requests and the governmental replies are included in the report. ${ }^{189}$ In addition, the Special Rapporteur received replies in 1991 to specific communications transmitted to governments in 1990, and which are also included in the sixth annual report. ${ }^{190}$ The report's most extensive investigations concerned incidents reported in Iraq, ${ }^{191}$ which also received particular mention in the concluding section of the report for its repression of the Shia religious community. ${ }^{192}$

The detail of the inquiries, the information contained in the governmental replies, and the very existence of governmental dialogue with the Special Rapporteur should be of assistance in combatting incidents of religious intolerance and discrimination. The constitutions or basic laws of most countries explicitly or implicitly prohibit, and sometimes criminalize, intolerance or discrimination based on religious belief, but legislative and administrative reforms to clarify protections and avenues of redress are still needed in most countries. ${ }^{193}$ On the issue of "cults" or "sects," the Special Rapporteur noted that the relative tolerance reflected in the replies contrasted with his experience of profound persecution of religious movements characterized in such a fashion. ${ }^{194}$ Regarding the tolerance of nonbelievers, "only Western countries specifically referred to the 'negative freedom' of holding no religious beliefs." 195

188. Id. at 160.

189. Responding countries included China, Egypt, El Salvador, Greece, India, Iraq, Morocco, and Thailand.

190. Replies from communications sent in 1990 were received from the governments of the Dominican Republic, Ghana, and Pakistan.

191. See id. at 39-73.

192. Id. at 176 .

193. Id at 178-80.

194. Id at 177 .

195. Id. 
In his conclusions and recommendations, the Special Rapporteur viewed as encouraging the increasing cooperation he had been receiving from governments, and the willingness expressed by many governments to receive advisory services in this field from the Centre for Human Rights. ${ }^{196}$ The positive developments in Eastern Europe in recent years received particular mention. The responses to the questionnaire also helped the Special Rapporteur develop his views on the issue of conscientious objection: namely that decisions concerning their status should be made by an impartial, nonmilitary tribunal or a civilian court (with rights to counsel and to appeal to a civilian judicial body), and that objectors should be exempted from combat but could be required to perform alternative service in the public interest.

As with the case of the renewal of the mandate of the Special Rapporteur on torture, the Commission engaged in some debate on issues related to the renewal of the mandate of the Special Rapporteur on religious intolerance. A number of governments and NGOs commended the work of the Special Rapporteur and the present report, and urged a three-year renewal of his mandate. ${ }^{197}$ Although some governments expressed reservations, the resolution calling for continued implementation of the Declaration on the Elimination of All Forms of Intolerance and Discrimination Based on Religious Belief, and extending the mandate of the Special Rapporteur for another three years, was adopted without a vote. ${ }^{198}$

\section{F. Working Group on Arbitrary Detention}

In 1991, the Commission created a new Working Group on Arbitrary Detention. The resolution creating the new Working Group assigned the task "of investigating cases of detention imposed arbitrarily or otherwise inconsistently with the relevant international standards set forth in the Universal Declaration of Human Rights or in the relevant international legal instru-

196. Id. at 173,179 .

197. Those governments making strong statements in favor of renewal (usually explicitly urging three years) included Australia, Belgium, Canada, Costa Rica, Ireland, the Netherlands, Russia, Switzerland, and the United Kingdom. Nongovernmental organizations speaking on the subject and urging renewal of the mandates included the International Commission of Jurists, the International Federation of Human Rights, and Pax Romana. The representative of the Philippines expressed the opinion that the work of the Special Rapporteur was "almost completed" and that the mandate should only be extended for one year. Iran was another government speaking strongly against the practice of "automatic or nearautomatic $c^{\prime \prime}$ renewal of the mandates of the theme mechanisms. The Philippines and Iran were among the governments that also suggested that existing mandates be more narrowly construed.

198. C.H.R. Res. 1992/17, 48 U.N. ESCOR Supp. (No.2) at 55, U.N. Doc. E/CN.4/1992/84 (1992). 
ments." 199 The Working Group was given a three-year mandate to investigate cases of arbitrary detention and report to the Commission. Louis Joinet (France) was elected Chairman/Rapporteur of the Working Group.

The Working Group held its first meeting in September 1991, and presented a report to the Commission in which it described its views of its mandate, its working methods, and the principles applicable to the cases submitted to it. ${ }^{200}$ The working methods adopted at this meeting were largely based on the approach of the Working Group on Enforced or Involuntary Disappearances. ${ }^{201}$ At its first meeting, the Working Group adopted a model questionnaire to gather information on instances of arbitrary detention, and why the complainant deems the detention arbitrary. While the Working Group will consider communications received regarding instances of arbitrary detention that do not use the model questionnaire, provided that adequate information is conveyed, persons filing complaints with the Working Group are encouraged to use or at least take the questionnaire into account whenever possible. ${ }^{202}$ In the usual case, the Working Group asks the governments concerned to reply within ninety days from the date of transmittal. In addition to procedures to report on instances of arbitrary detention, receive and investigate complaints, receive government replies, take decisions, and make recommendations regarding cases, the Working Group also has an urgent action capability for those cases in which there are grounds to believe that detention constitutes a serious danger to the detainee's health or life, or in other circumstances where urgent action is warranted. ${ }^{203}$

After its first session, the Working Group in October 1991 sent communications regarding 223 alleged cases of arbitrary detention, to seventeen governments. ${ }^{204}$ It obtained information regarding a number of these cases indicating that the detainee had been released, and other replies that required further clarification. After its second session, the Working Group sent another fifteen communications to nine governments, including one urgent action communication to the government of the Lao People's Democratic Republic. ${ }^{205}$ At the time of completion of the report, the Working Group was

199. C.H.R. Res. 1991/42, 47 ESCOR Supp. (No.2) at 105, U.N. Doc. E/CN.4/1991/91 (1991).

200. U.N. Doc. E/CN.4/1992/20 (1992).

201. Id. at 4 .

202. See id. at 4-7, and Annex II (model questionnaire).

203. Id. at 6 .

204. The governments who received communications from the Working Group, and the number of cases transmitted, are as follows: Bhutan (6), Chile (3), China (15), Cuba (64), Iran (9), Lao People's Democratic Republic (2), Libya (9), Malawi (3), Mexico (1), Morocco (24), Myanmar (3), Peru (1) Sudan (18), Syria (60), Tunisia (1), Turkey (2), and Tanzania (2). ld., at 7 .

205. The governments receiving the second series of communications, with the numbers of cases transmitted, were as follows: China (5), Egypt (1), Israel (2), Republic of Korea (1), Lao People's Democratic Republic (2), Malaysia (1), Nigeria (1), Saudi Arabia (1), and Uganda (1). 
still awaiting replies from the governments of China, Iran, Lao People's Democratic Republic, Libya, Malawi, Morocco, Myanmar, Sudan, Peru, Turkey, and Tanzania. Since completion of the report, the Working Group contacted seven governments regarding additional cases of arbitrary detention. ${ }^{206}$

In its first year of operation, the new Working Group has already contributed to more effective protection of human rights through the United Nations. The Commission's resolution regarding the Working Group expresses satisfaction at the diligence with which it has pursued its tasks. ${ }^{207}$ (Its three-year mandate was not subject to renewal during the 1992 session.) The Commission also adopted a resolution calling on all states without a habeas corpus mechanism by which a court can decide on the lawfulness of a person's detention, to adopt such a mechanism. ${ }^{208}$

\section{G. Children}

The Commission received the first full report ${ }^{209}$ of the new Special Rapporteur on the Sale of Children, Child Prostitution, and Child Pornography. The Special Rapporteur Vitit Muntarbhorn (Thailand) had been appointed in September 1990 by the authority of a Commission resolution that year, ${ }^{210}$ and because of the short time between his appointment and his first report (January 1991) was only able to present a preliminary report to the 1991 Commission, outlining his intended activities. ${ }^{211}$ In the intervening year, the Special Rapporteur gathered information on the relevant problems, sent a questionnaire to a broad range of countries, NCOs, and concerned individuals, took some field visits, and began the process of intervening on behalf of individuals experiencing human rights violations within the mandate. ${ }^{212}$ Although questions had existed regarding whether the Special Rapporteur had urgent action authority, he did send an urgent action intervention to the government of Pakistan on behalf of a young girl named Fatma who was alleged to have been kidnapped and brought to Pakistan from Bangladesh. At the time of the 1992 report, no progress had been made in locating the girl. ${ }^{213}$

206. U.N. Press Release HR/3025 (11 Feb. 1992).

207. C.H.R. Res. 1992/28, 48 U.N. ESCOR Supp. (No.2) at 78, U.N. Doc. E/CN.4/1992/84 (1992).

208. C.H.R. Res. 1992/35, 48 U.N. ESCOR Supp. (No.2) at 92, U.N. Doc. E/CN.4/1992/84 (1992).

209. U.N. Doc. E/CN.4/1992/55, 48 U.N. ESCOR Supp. (No.2) at 333, U.N. Doc. E/CN.4/ 1992/84 (1992).

210. C.H.R. Res. 1990/68, 46 U.N. ESCOR Supp. (No.2) at 145, U.N. Doc. E/CN.4/1990/94 (1990).

211. U.N. Doc. E/CN.4/1991/51 (1991).

212. U.N. Doc. E/CN.4/1992/55 (1992), at 5-6.

213. $/ d$. at 6 . 
The 1992 report stressed the key role of poverty in causing the sale of children, child prostitution, and child pornography. ${ }^{214}$ Other factors include the family breakdown resulting from the increased mobility of modern life, increased materialism, consumerism, and sexism. ${ }^{215}$ Access to education and to job opportunities is therefore part of the solution, as are interdisciplinary "legal, economic, social, cultural, political, and even environmental" strategies. ${ }^{216}$

Regarding the preliminary issue of defining the term "child," the Special Rapporteur had recourse to the 1990 Convention on the Rights of the Child, which defines child as any human being under the age of eighteen (unless applicable law provides that the age of majority is reached earlier). ${ }^{217}$ The report also advocates a flexible definition of the term "sale," i.e., it recognizes that the key to the concept is preventing exploitation of children. ${ }^{218}$ The issues addressed under the heading "sale of children" included problems associated with adoptions, child labor exploitation, human organ transplantation, and other forms of sale (possibly including, for example, sale of children for use in armed conflicts, or child abduction/disappearance). ${ }^{219}$ The report contained an analysis of each issue, including the current state of laws and practices on the national and international levels, and future trends in each category. There are also detailed discussions of child prostitution and child pornography, and the current state of the laws and practices relating to each, including future trends.

During the year, the Special Rapporteur visited two countries at the invitation of the governments concerned. The first visit, to the Netherlands, occurred from 10 to 15 June 1991, and the second visit, to Brazil, occurred from 6 to 19 January 1992. The purpose of the Netherlands visit was to assess the profile of a developed country with respect to the issues within the Special Rapporteur's mandate. The primary problems in the Netherlands with respect to the mandate are not commercial adoption or child labor (although some problems do exist in these areas), but child prostitution and child pornography. Child prostitution (under 18 ) is illegal; adult prostitution is not (although it is regulated, and exploiters of prostitution, such as procurers and brothel owners, are currently outlawed at least in theory). ${ }^{220}$ The Special Rapporteur noted that more effective law enforcement relating to procurers of child prostitutes was needed. ${ }^{221}$ A striking revelation in 1984 that seventy percent of the child pornography confiscated by US Customs came from the Netherlands (through transhipment, as opposed to original production) re-

214. Id. at 2 .

215. Id.

216. Id. at 5 .

217. Id. at 7 .

218. Id. at 8 .

219. Id. at 8-26.

220. Id. at 51 .

221. Id. 
sulted in a stringent new Dutch law against child pornography. ${ }^{222}$

The Special Rapporteur's recommendations regarding the Netherlands (and to some extent, by extrapolation, other developed countries) focused on expanding existing programs and protections, as well as better enforcement of existing laws. For example, the Special Rapporteur called for expansion of existing education and training programs for minority groups in order to decrease the vulnerability of their children to exploitation as child labor. ${ }^{223}$ In order to decrease the incidence of child prostitution, the Special Rapporteur recommended more funding and programs to address the problems of families and of migrant worker/immigrant populations. ${ }^{224} \mathrm{He}$ also recommended the creation of a special section of the police to deal with the issue of child abuse and exploitation, and increased law enforcement efforts to deal with child prostitution, particularly the "grey area" of children between the ages of sixteen (the age of consent for sexual relations) and eighteen (the age of majority). ${ }^{225}$

The visit to Brazil was the subject of a separate addendum to the Special Rapporteur's primary report. ${ }^{226} \mathrm{His}$ visit took place immediately prior to the 1992 Commission on Human Rights. The killings of Brazilian street children in recent years (reportedly by armed "death squads" or government-affiliated paramilitary groups "cleaning up the streets") formed the context of this report. There are progressive laws on the books in Brazil, including a new "Statute of the Child and Adolescent" which guarantees the rights of children. ${ }^{227}$ Nonetheless, there remains a wide gap between theory and practice, and the Special Rapporteur noted that both law enforcement personnel, often from economically disadvantaged sectors of the community with priorities other than children, and judges and lawyers, from less disadvantaged sectors, need to improve their implementation of the statute and other protective laws. ${ }^{228}$ Both child prostitution and child pornography are illegal in Brazil. Yet the problem of child prostitution is prevalent in both urban and rural areas, ${ }^{229}$ and sporadic cases of child pornography continue to appear. ${ }^{230}$ The Special Rapporteur had also received evidence of paramilitary groups associated with the government (e.g., off-duty security forces or police) being responsible for violence against street children in Brazil, particularly children of Afro-Brazilian origin. ${ }^{231}$

222. Id. at 54 .

223. Id. at 55 .

224. Id. at 56 .

225. Id. at 57.

226. See U.N. Doc. E/CN.4/1992/55/Add.1 (1992).

227. Id at 5 .

228. Id. at 6 .

229. Id. at 9 .

230. Id. at 10 .

231. See, e.g., id. at 5-6. 
The Special Rapporteur concluded that the priority of child development and protection in Brazil "raises fundamental issues of social justice and equity. ${ }^{232}$ Among his more significant recommendations are (1) the creation of registries of children and families involved in adoptions, (2) a new ombudsman or entity to hear the grievances of the public against law enforcement personnel, (3) a focus on enforcement against exploitation of child labor, particularly in the sectors of domestic service and agriculture (e.g., sugar plantations), and in small-scale factories, (4) pressure by tourist organizations as well as the government against sex tourism, and (5) stronger measures to implement existing laws against child prostitution and child pornography. ${ }^{233}$ It is noteworthy that in a statement to the Commission, the representative of Brazil mentioned that the results of a Chamber of Deputies' investigation on the problem of violence against children was being presented in Brazil at that very moment, and a national plan and commission to combat the problem of violence against children had been created..$^{234}$

The Special Rapporteur's general recommendations emphasized not only the need for better enforcement of existing laws, but also the need for preventive strategies to combat the causes of the human rights violations against children that are the subject of his mandate. ${ }^{235}$ He highlighted education, medical care, family planning facilities, job opportunities, and social security. He also recommended accession to the relevant international instruments, especially the Convention on the Rights of the Child. ${ }^{236}$ In its consensus resolution extending the mandate of the Special Rapporteur for another three years, the Commission endorsed the conclusions and recommendations contained in his report, while also inviting the Special Rapporteur to cooperate closely with the Committee on the Rights of the Child, the Working Group on Contemporary Forms of Slavery, and other United Nations bodies active in the areas covered by his mandate. ${ }^{237}$

\section{H. Internally Displaced Persons}

Several delegations and NGOs urged the establishment of a thematic mechanism for internally displaced persons. Although the Commission decided not to establish a thematic rapporteur, it did, however, request the SecretaryGeneral to designate a representative to gather information from all govern-

232. Id. at 11

233. Id. at 11-14.

234. See U.N. Press Release HR/3048 (27 Feb. 1992).

235. U.N. Doc. E/CN.4/1992/55 (1992), at 62.

236. Id. at 61 .

237. C.H.R. Res. 1992/76, 48 U.N. ESCOR Supp. (No.2) at 187, U.N. Doc. E/CN.4/1992/84 (1992). 
ments on the human rights issues related to internally displaced persons. ${ }^{238}$ The appointment of Mr. Francis $M$. Deng (Sudan) as special representative may indicate a significant step towards eventually establishing a thematic working group or Special Rapporteur for internally displaced persons.

\section{OTHER ACTIONS OF THE COMMISSION}

\section{A. Work of the Sub-Commission}

The work of the Sub-Commission on the Prevention of Discrimination and Protection of Minorities, and its relationship to the work of the Commission, continued to receive attention at the 1992 session.

The Sub-Commission is a subsidiary body of the Commission that meets every August for four weeks. It is composed of twenty-six nominally independent experts, nominated by their governments but elected by the entire Commission. The Sub-Commission has generated many important standards and reports used by the Commission, and it has also played the occasional role of addressing serious human rights problems that for one reason or another the Commission is unable or unwilling to address. The independence of the experts has sometimes been difficult to sustain, as a result of the fact that they are nominated by their governments. But in general the Sub-Commission experts are more independent in both theory and practice than the official government representatives who act on behalf of Commission members. This independence was strengthened somewhat in 1991 when, after considerable debate and procedural posturing, the Commission (and then ECOSOC) approved the ability of the Sub-Commission to act by secret ballot "when it so decides by a majority of those present and voting."239

In recent years, there have been concerns that the Sub-Commission has not provided the Commission with the most effective assistance possible, and has in some measure duplicated certain aspects of the Commission's work. ${ }^{240}$ This concern persists, and was expressed by a number of delegations during the 1992 Commission. ${ }^{241}$ The United States reiterated its view that the Sub-Commission duplicated work on topics that could be better handled

238. C.H.R. Res. 1992/73, 48 U.N. ESCOR Supp. (No.2) at 173, U.N. Doc. E/CN.4/1992/84 (1992).

239. See Parker \& Weissbrodt, supra note 1 , at 605-06.

240. Id. at 607 .

241. Delegations participating in the debate on the role of the Sub-Commission in 1992 were from countries as diverse as Australia, Austria, Brazil, Chile, China, France, Hungary, Iran, the Netherlands, Russia, and the United States. Many of these statements continued to be critical of inefficiencies in the Sub-Commission's work, while generally supportive of its basic role. 
by the Commission or other United Nations fora, including human rights and the environment; the right to housing; and economic, social, and cultural rights. The United States believed that the core work of the Sub-Commission in protecting minorities was more pressing than ever, and should be the focus of the Sub-Commission. ${ }^{242}$ The US position was generally echoed on this point by representatives of such diverse governments as Brazil, China, Hungary, and the Netherlands.

Nonetheless, Commission members recognized the usefulness of the studies of the Sub-Commission, its ability to act on some matters as to which the Commission is not able or willing to act, and its accessibility to NGOs, among the reasons that its work remains significant. ${ }^{243}$ At its August 1991 session, the Sub-Commission adopted the report of its own working group on better organization, and established an intersessional working group to consider in more detail the rationalization of its work and agenda. In his Report as Chair of the Sub-Commission, Louis Joinet pointed out that the 1991 reform - pursuant to which secret ballot voting was allowed on certain country situations - had resulted, as expected, in a stronger and more independent Sub-Commission, as well as appreciable time savings (since "political" statements were rendered less necessary in light of the secret ballot). ${ }^{244}$

The Commission endorsed and welcomed these efforts at streamlining the work of the Sub-Commission, and invited the intersessional working group to make recommendations on a number of points, including (1) initiatives for better coordination with the Commission and other United Nations organs active in the field of human rights, (2) ways of strengthening the independence of the experts of the Sub-Commission, and (3) ways of improving the working methods of the Sub-Commission, including the allocation of speaking time among the experts, the procedures for timely completion of topical studies, the designation of rapporteurs and commentators, the procedure for evaluation and monitoring of study recommendations, the format and number of resolutions, and the rationalization of the agenda. ${ }^{245}$ Cuba lost, by a vote of thirty-one to eleven (with six abstaining), an effort to delete the detailed guidelines of the Commission with respect to the intersessional working group. Iran and Syria then failed in their attempt to defer consideration of the entire draft resolution of the Commission on the Sub-Commission's work, allegedly to allow governments to "more thoroughly consider this important subject." The Commission's resolution on the work of the Sub-Commission, incorporating the Commission's guidelines

242. Id.

243. See U.N. Press Release HR/3029 (13 Feb. 1992).

244. U.N. Doc. E/CN.4/1992/46 (1992).

245. C.H.R. Res. 1992/66, 48 U.N. ESCOR Supp. (No. 2) at 152, U.N. Doc. E/CN.4/1992/84 (1992) 
along the lines described above, was thus adopted (by a vote of forty for, none against, and eleven abstaining). ${ }^{246}$

Since 1990, the Commission has implemented the practice of electing half of the Sub-Commission's members every even-numbered year. This year, therefore, thirteen of the twenty-six positions were filled by the Commission. Pursuant to the rules for geographical distribution of members from the five regions of the world recognized in the United Nations system, this allocation meant that there would be four members from African states, two from Asian states, two from Latin American states, two from East European states, and three from West European and other states. The elections went smoothly for the most part, although there remained concern that some of the nominees of governments were more "political" appointees than true experts in the realm of international human rights. This concern, of course, springs from the requirement that the Sub-Commission's members be objective and independent experts who do not act on behalf of their governments. It was also noteworthy that most of the successful candidates had previously served on the Sub-Commission. Twelve of the thirteen Sub-Commission members, including loan Maxim (Romania), were elected on 2 March 1992. ${ }^{247}$ Unfortunately, it took a number of rounds of voting in order to select the other member of the Sub-Commission from the East European region. The preliminary rounds of voting were inconclusive because of the failure of any one of the remaining three candidates (from Poland, the Ukraine, and Hungary) to achieve a majority. In the evening of the final day of the Commission, however, the Polish candidate withdrew, and the candidate from the Ukraine $^{248}$ was elected on the ninth ballot by a vote of twenty-eight to twenty-two of the eligible votes counted.

As usual, the Commission also adopted a number of resolutions and decisions proposed by, and authorized the continued work of, the SubCommission. Many of these resolutions relate to the administration of justice, such as those regarding states of emergency ${ }^{249}$ and the independence of the judiciary. ${ }^{250}$ Other resolutions proposed by the Sub-Commission and adopted

246. Id. Those abstaining were Burundi, China, Cuba, Ghana, Indonesia, India, Iraq, Pakistan, Somalia, Sri Lanka, and Syria.

247. Elected from the African states were Ahmed Khalifa (Egypt), Fisseha Yimer (Ethiopia), Halima Embarek Warzazi (Morocco) and Said Naceur Ramadhane (Tunisia). From Asia: Muksum-Ul-Hakim (Bangladesh) and Ribot Hatano (Japan). From Latin America: Clemencia Forero Ucros (Colombia) and Miguel J. Alfonso Martinez (Cuba). From the West European and other group: Marc Bossuyt (Belgium), Asbjorn Eide (Norway) and Linda Chavez (United States).

248. Volodymyr Boutkevitch.

249. C.H.R. Dec. 1992/107, 48 U.N. ESCOR Supp. (No.2) at 210, U.N. Doc. E/CN.4/1992/ 84 (1992).

250. C.H.R. Res. 1992/33, 48 U.N. ESCOR Supp. (No.2) at 89, U.N. Doc. E/CN.4/1992/84 (1992). 
by the Commission related to freedom of opinion and expression, ${ }^{251}$ human rights and youth, ${ }^{252}$ human rights and the environment, ${ }^{253}$ the rights of detained United Nations staff members, ${ }^{254}$ and the rights of indigenous peoples, ${ }^{255}$ among others.

\section{B. The World Conference and the Year of Indigenous People}

Planning for the 1993 World Conference on Human Rights proceeded apace, as indicated by the Secretary-General's Note on Preparations for the World Conference, which was submitted to the Commission. ${ }^{256}$ The note set forth the outline of planned public information activities, regional preparatory meetings, and ongoing studies relating to the World Conference. Basic funding arrangements were in place, including a Voluntary Fund for financial support for persons from developing countries, and rough ideas for the agenda had been suggested. The first preparatory meeting took place in September 1991 and was reportedly constructive. The rules of procedure for the Conference, the provisional agenda, and the documentation needed would be established at the second meeting of the preparatory committee. Many delegations stressed the key role of the preparatory meetings in ensuring the success of the Conference and increasing the likelihood of concrete results. ${ }^{257}$ A number of governments as well as NGOs emphasized the importance of including NGOs as active participants in the Conference, including broad funding support for representatives of NGOs and even governmental officials from developing countries.

There has been considerable uncertainty regarding the site of the Conference. Originally Morocco and Hungary each expressed an interest in serving as host for the Conference, but Germany's offer was accepted. Then, reportedly because of the unanticipated costs associated with reunification, Germany withdrew its offer to host the Conference and Italy offered to serve

251. C.H.R. Res. 1992/22, 48 U.N. ESCOR Supp. (No.2) at 68, U.N. Doc. E/CN.4/1992/84 (1992).

252. C.H.R. Res. 1992/49, 48 U.N. ESCOR Supp. (No.2) at 117, U.N. Doc. E/CN.4/1992/84 (1992).

253. C.H.R. Dec. 1992/110, 48 U.N. ESCOR Supp. (No.2) at 211, U.N. Doc. E/CN.4/1992/ 84 (1992).

254. C.H.R. Res. 1992/26, 48 U.N. ESCOR Supp. (No.2) at 75, U.N. Doc. E/CN.4/1992/84 (1992).

255. C.H.R. Dec. 1992/114, 48 U.N. ESCOR Supp. (No.2) at 213, U.N. Doc. E/CN.4/1992/ 84 (1992).

256. U.N. Doc. E/CN.4/1992/57 (1992).

257. See, e.g., Statement of the Representative of the Russian Federation, cited in U.N. Press Release HR/3032 (1992), at 7. 
as host. ${ }^{258}$ Even during the Commission, however, Austria indicated an interest in hosting the Conference, and now it appears that the Conference will take place in Austria.

Doubts persisted in some quarters regarding the value of the Conference, not only as to whether the Conference might be duplicative of the activities of the Commission, but (usually in private) as to whether the Conference could be a vehicle for eliminating or reducing effective human rights mechanisms in the name of "streamlining" procedures or enhancing efficiency. The criticisms of the idea of the Conference came mainly from persons who thought that the goals of the Conference and the agenda and preparatory plans were insufficiently defined. The public statements of most governments and NGOs, however, remained supportive and even enthusiastic about the Conference and the preparatory work that had been done to date. A number of speakers referred to the potential historic significance of the Conference.

In their floor statements on the Conference, delegations positioned themselves to ensure that their human rights concerns were prominent in the Conference agenda. Bolivia, China, Ecuador, India, Indonesia, Kenya, Libya, Morocco, Senegal, Uruguay, and Venezuela, for example, made it a point to stress the importance of considering economic rights and issues related to poverty and development. ${ }^{259}$ On behalf of the European Community, Portugal stated that a major concern would be reaffirming the indivisibility of political and civil rights, on the one hand, and economic, social, and cultural rights, on the other hand. ${ }^{260}$ Australia suggested that each government should prepare a "Human Rights Action Plan" setting forth the steps that it would take, such as ratification of certain international instruments, removal of treaty reservations, and creation of training programs, to improve its human rights performance. ${ }^{261}$ Among the other topics mentioned by governments and NGOs as important subjects for consideration at the Conference were evaluation of existing United Nations machinery in the field of human rights and consideration of reforms to enhance the effectiveness of the United Nations. In this regard, it was suggested that detailed consideration be given to possible creation of an emergency response mechanism (similar to the proposal of Austria discussed below), ${ }^{262}$ or creation of a World Court for human rights and/or a High Commissioner for Human Rights, both ideas that have been proposed before but never accepted by the Commission.

In terms of strategies for human rights implementation, areas of particular interest included public eduction and publicity as well as training of law

258. Statement by the government of the Philippines on 28 February 1992. See U.N. Doc. E/ CN.2/1992/SR.45 (1992).

259. See, e.g., id.

260. Id. at 6-7.

261. Id.

262. See infra notes $297-300$ and accompanying text. 
enforcement officers and the judiciary, strengthening national and regional institutions for promoting human rights, preventive (versus reactive) approaches to combatting violations, and decreasing the impunity currently given in many countries to human rights violators. Particular targets of human rights violations that were highlighted by speakers as worthy of special concern were women, children, refugees, and indigenous populations. Specific substantive topics that several speakers suggested as important to include on the agenda were problems of minorities, ethnic unrest, and issues relating to human rights and the environment.

In its resolution on the subject (adopted without a vote), the Commission continued to express support for the Conference and encouraged the widest participation by states. The resolution also called upon the Preparatory Committee to consider the suggestions made by the Commission regarding the agenda and work of the Conference. ${ }^{263}$

1993 will also be the International Year for the World's Indigenous People, and the Commission adopted a separate resolution on that subject welcoming the year, encouraging states to take part in the planned program of activities, and calling for continued coordination among United Nations organs and NGOs regarding projects to be implemented during the year. ${ }^{264}$

\section{Draft Declaration on Disappearances}

For several years, the Commission and Sub-Commission have been working towards a Draft Declaration on the problem of enforced or involuntary disappearances. At last year's session, concerns about several aspects of the Sub-Commission's Draft Declaration on the Protection of All Persons from Enforced or Involuntary Disappearances ${ }^{265}$ resulted in delay of consideration of the Draft Declaration for one year, and creation of an open-ended Working Group of the Commission to meet for two weeks prior to the Commission and consider the draft in more detail. ${ }^{266}$ At the meetings of the open-ended Working Group, which were well attended not only by governments, but by nongovernmental organizations and observers, the Draft Declaration was considered in detail, "paragraph by paragraph and article by article." ${ }^{267}$ The result was the report of the Working Group on the Draft Declaration, ${ }^{268}$

263. C.H.R. Res. 1992/37, 48 U.N. ESCOR Supp. (No.2) at 94, U.N. Doc. E/CN.4/1992/84 (1992).

264. C.H.R. Res. 1992/45, 48 U.N. ESCOR Supp. (No.2) at 109, U.N. Doc. E/CN.4/1992/84 (1992).

265. U.N. Doc. E/CN.4/Sub.2/1990/32 (1990).

266. See Parker \& Weissbrodt, supra note 1, at 610-11.

267. U.N. Doc. E/CN.4/1992/19/Rev.1 (1992), at 4.

268. Id. 
which was presented to the Commission by its Chair and Rapporteur, Ms. Beatrice le Fraper du Hellen (France).

In addition to other, more substantive changes, the title of the Declaration was changed to "Declaration on the Protection of All Persons from Enforced Disappearance." ${ }^{269}$ In its preamble, the new Draft Declaration provides a shorthand definition of "enforced disappearances" as the phenomenon of persons being:

arrested, detained or abducted against their will or otherwise deprived of their liberty by officials of different branches or levels of government, or by organized groups or private individuals acting on behalf of, or with the support, direct or indirect, consent or acquiescence of the government, followed by a refusal to disclose the fate or whereabouts of the persons concerned or a refusal to acknowledge the deprivation of their liberty, thereby placing such persons outside the protection of the law. ${ }^{270}$

Resolving the debate from prior years as to whether such actions constitute a crime against humanity, the Draft Declaration takes the position that "the systematic practice of such acts" is "of the nature of a crime against humanity." ${ }^{\prime 21}$ The issue from last year as to whether to include the principle of "universal jurisdiction" was resolved in the negative.

The Draft Declaration itself is composed of twenty-one articles. The articles provide that any act of enforced disappearance is "an offense to human dignity" and "a grave and flagrant violation of the human rights ... proclaimed in the Universal Declaration" and the relevant international instruments, and that "no state shall practice, permit or tolerate enforced disappearances." ${ }^{272}$ The Declaration sets forth some of the key measures that states should take to prevent and terminate acts of enforced disappearances on their territory, including making such acts criminal offenses punishable by appropriate criminal penalties and subjecting perpetuators and the culpable states or state authorities to civil liability. ${ }^{273}$

Measures are also mandated to ensure that there are clear rules and a clear chain of command as to which authorized officials are entitled to order detention. ${ }^{274}$ There are no circumstances whatsoever, including war or threat of war, that may be invoked to justify enforced disappearances. ${ }^{275}$ The right to prompt and effective recourse to a judicial remedy is required, with competent national authorities being given the right of access to detention facilities or places where there is reason to believe that persons may be

269. Id. at 7 .

270. Id. at 8 (Annex).

271. Id.

272. Id. at 9 (arts. 1, 2).

273. Id. at 10 (arts. 4, 5).

274. Id. at 12 (art. 12).

275. Id. at 10 (art. 7). 
held. ${ }^{276}$ States are also required to maintain both at the place of detention and in a centralized location, an accurate and up-to-date register of all persons detained, and to provide information on the detention to family members, counsel, or others with a legitimate interest in the information. ${ }^{277}$ States are required to thoroughly investigate cases of alleged disappearance, to suspend persons allegedly responsible during the investigation, and to punish through civilian (and not military) courts the persons responsible for acts of enforced disappearance, unless such persons are to be extradited under applicable international agreements. ${ }^{278}$ There are provisions ensuring that statutes of limitations are long, in accord with the gravity of the offenses at issue, that no amnesty law shall apply in cases of enforced disappearance, and that victims and their dependents are entitled to adequate compensation. ${ }^{279}$

Although a number of states and nongovernmental organizations pointed to ways in which the Draft Declaration could, in their estimation, have been strengthened, those speaking unanimously welcomed the Declaration as an important step forward in promoting and protecting human rights. ${ }^{280}$ In its resolution approving the Draft Declaration by consensus and forwarding it to ECOSOC (and, ultimately, the General Assembly) for adoption, the Commission also recommended that after its adoption by the General Assembly, the Declaration be disseminated as widely as possible. ${ }^{281}$

\section{Declaration on Minorities}

After fourteen years of effort by Commission and Sub-Commission members and nongovernmental organizations, the Commission concluded its Draft Declaration on Minorities. The Commission's Working Group completed its second reading of the Draft Declaration in December 1991, shortly before the opening of the Commission's session, and produced its report for consideration by the Commission. ${ }^{282}$ In introducing the Draft Declaration, the Chair of the Commission's Working Group (Zagorka Ilic - Yugoslavia) spoke

276. Id. at 11 (art. 9).

277. Id. at 11 (art. 10).

278. Id. at 12-13 (arts. 14, 16).

279. Id. at 13-14 (arts. 17, 18, 19).

280. Among those states with strong statements welcoming the adoption of the Draft Declaration were Australia, Austria, Bulgaria, Canada, Czechoslovakia, Chile, Cuba, Italy, Japan, the Netherlands, New Zealand, Norway, Peru, Portugal, Spain, Venezuela, and the United Kingdom. NGOs speaking on the subject included the International Commission of Jurists (speaking on behalf of six NGOs), FEDEFAM, the Association of American Jurists, and the International Human Rights Law Group.

281. C.H.R. Res. 1992/29, 48 U.N. ESCOR Supp. (No.2) at 80, U.N. Doc. E/CN.4/1992/84 (1992).

282. U.N. Doc. E/CN.4/1992/48 and Corr.1 (1992). 
of the international climate that made finalization of the Draft possible, as well as the difficulties that had been presented by the attempt to define the term "minority." 283 It was ironic that the Chair of the Working Group was Yugoslavian and the text of the Draft Declaration originated with a proposal by the government of Yugoslavia in 1978; the Commission adopted the Draft Declaration at the very time when Yugoslavia was facing dissolution due to problems of minorities and ethnic unrest. In case anyone missed the irony, the representatives of Australia and the Netherlands called attention to the tragic situation in Yugoslavia during their remarks on the Declaration. ${ }^{284}$ Indeed, from the opening session Jan Martenson called attention to the importance of the Declaration in a time of increasing ethnic unrest, ${ }^{285}$ and during the debate a number of speakers from governments and nongovernmental organizations referred to the many conflicts raging in the world involving minorities, including conflicts in Guatemala and NagornoKarabagh, among others.

The Sub-Commission had tried unsuccessfully to develop an acceptable definition for the term "minority." Since the issue is left open in the Declaration and in general international law, much of the responsibility for developing suitable definitions will fall to the states. The Declaration, however, does provide a framework for states, the United Nations, and other international actors and organizations to identify whether minority issues are present in a given situation, and to act accordingly. ${ }^{286}$

On the issue of whether minority rights would be collective rights or individual rights, the Draft Declaration affirms that individual members of minority groups, at least in the first instance, possess the rights. This issue had been controversial; until the final meeting of the Working Group, the phrase "persons belonging to" before all references to minorities had been in brackets throughout the text of the Draft Declaration. In the final version, the brackets were removed by agreement of the Working Group. ${ }^{287}$ Article 3 of the final version of the Draft Declaration thus states that "persons belonging to minorities may exercise their rights ... individually as well as in community with other members of their group, without any discrimination." Several delegations, including those of the Netherlands and the United States, noted their satisfaction with this resolution of the issue.

The Draft Declaration sets forth principles governing the protection of persons belonging to minorities, requires states to create the conditions necessary to ensure enjoyment of these rights, and provides for state co-

283. See U.N. Press Release HR/3021 (7 Feb. 1992).

284. See id. at 4.

285. U.N. Press Release HR/3005 (27 Jan. 1992), at 3.

286. See comments of the representative of Austria, cited in U.N. Press Release HR/3021 (7 Feb. 1992), at 3.

287. See U.N. Doc. E/CN.4/1992/48 (1992), at 3. 
operation on issues relating to minorities. The preamble refers to the inspiration provided by Article 27 of the International Covenant on Civil and Political Rights regarding the rights of persons belonging to ethnic, religious, or linguistic minorities, and the fact that promotion and protection of such rights contributes to the political and social stability of states. ${ }^{288}$

The operative language provides that states shall take appropriate legislative and other measures to protect the existence and the national or ethnic, cultural, religious and linguistic identity of minorities within their territories, and shall encourage conditions for promoting that identity. ${ }^{289} \mathrm{~A}$ major issue during the drafting process had been whether to go beyond mere prohibitions on discrimination, to provide affirmatively that the separate cultures and languages of minorities should be preserved. The Draft Declaration resolves that issue by taking the more affirmative approach.

For example, in regard to official language and movements in many other countries toward official languages, the Declaration refers to the rights of minorities (1) to enjoy their own culture and to use their own language, in private and in public, without being subject to any form of discrimination, and (2) wherever possible, to learn and receive instruction in their mother tongue. ${ }^{290}$ Members of minorities are also guaranteed the rights to participate effectively in public life, to establish and maintain their own associations as well as contacts within their own group or across frontiers, and to express their characteristics and develop their culture, language, religion, and customs (unless specific practices are in violation of national and international law). ${ }^{291}$ Further, in order to avoid the possibility of conflict with the principle of equality in the Universal Declaration as states take measures to implement the Draft Declaration on Minorities, the text provides that measures taken by states to ensure the effective enjoyment of [minorities' rights] "shall not prima facie be considered contrary to the principle of equality contained in the Universal Declaration."

A number of delegations and nongovernmental organizations referred to the deficiencies of the Draft Declaration, including the lack of a clearcut definition of "minority" and the general nature of some of the language in the Draft Declaration. ${ }^{292}$ Several speakers reiterated the limited nature of the standards set forth in the Declaration, and looked forward to further international instruments on minority rights (such as a Declaration on the Rights of Indigenous Peoples) as well as further mechanisms (possibly in-

288. Id. at 16 (Annex l).

289. Id. at 17 (art. 1).

290. Id.

291. Id. at 18-19 (arts. 2, 4).

292. See, e.g., the comments of the representative of Hungary, cited in U.N. Press Release HR/3021 (7 Feb. 1992), at 3, or the comments of the representative of the Minority Rights Group, U.N. Press Release HR/3022 (7 Feb. 1992), at 3. 
cluding a Special Rapporteur on Minorities) $)^{293}$ as the international community continues to address minority issues. The representative of Austria suggested that the Declaration was best viewed not as a binding convention (which it is not), but as a political directive giving significant guidance on the meaning of the international standards set forth in Article 27 of the International Covenant on Civil and Political Rights. ${ }^{294}$

All of the speakers addressing the Draft Declaration, despite their concerns, concluded that it was a significant document that did clarify the meaning of minimum international standards in this difficult area. It also demonstrated the importance of the issue in the current international environment, and offered a valuable tool in future efforts to protect human rights and remove sources of domestic and international conflict. It is anticipated that the Draft Declaration, once adopted, will work in conjunction with other international initiatives, including the more comprehensive texts developed by the Conference on Security and Cooperation in Europe (CSCE). The Commission resolution approving the Draft Declaration and forwarding it to ECOSOC and the General Assembly for adoption was adopted by consensus. ${ }^{295}$

In a related resolution, the Commission endorsed the continued work of the Sub-Commission on ways and means to facilitate the peaceful and constructive solution of problems involving minorities. Hence, the Commission endorsed the cooperative efforts of the Sub-Commission's Special Rapporteur on Minorities Asbjorn Eide (Norway) and the Secretary-General, the continued consultations with and visits to states by the Special Rapporteur to gain first-hand information on the problems of minorities, and approval of the request for a new report by the Special Rapporteur. ${ }^{296}$

\section{E. Emergency Response Mechanism}

A frustration often expressed by Commission members and persons who follow the Commission's work is the sometimes glacial pace of the progress achieved by the Commission. The problem was tackled in part by the innovative proposal of Austria for an emergency response mechanism to deal

293. This idea was also mentioned by Jan Martenson in his opening statement to the Commission. U.N. Press Release HR/3005 (27 Jan. 1992), at 3.

294. See comments of the representative of Austria, cited in U.N. Press Release HR/3021 (7 Feb. 1992), at 3.

295. C.H.R. Res. 1992/16, 48 U.N. ESCOR Supp. (No.2) at 54, U.N. Doc. E/CN.4/1992/84 (1992).

296. C.H.R. Dec. 1992/112, 48 U.N. ESCOR Supp. (No.2) at 212, U.N. Doc. E/CN.4/1992/ 84 (1992). 
with grave situations of human rights violations between sessions of the Commission. ${ }^{297}$

As proposed by Austria, the mechanism would enable the Commission to react, without delay, to acute situations arising from gross violations of human rights. From nominations by the regional groups, the Secretary-General is required to maintain a list of experienced and impartial independent experts acting in their personal capacity. In the event of an acute situation involving gross violations of human rights, any state member of the United Nations may direct a written request to the Secretary-General to request immediately the views of the government of the country where the event takes place. The government's reply must be submitted within one week of receiving the Secretary-General's request. Commission members will then receive the original written request and the governmental reply from the Secretary-General and will have one more week to decide whether to invoke the emergency response mechanism.

If a majority of Commission members decide to do so, the SecretaryGeneral will promptly invite the Commission's Bureau to appoint a group of five experts with relevant experience, from the list maintained by the Secretary-General, to collect information on the situation and issue a report with conclusions and recommendations. It may be necessary to engage in a fact-finding visit to the state concerned, but such a visit can only be conducted with the consent of the relevant state. The report of the expert group would then be transmitted to the state concerned, with the expectation that within two weeks of receipt it will present to the Secretary-General its reactions and information on any action it has taken or intends to take. The report with the state's reaction will then be forwarded on a confidential basis to the other members of the Commission and to any relevant thematic rapporteurs or working groups. The Commission may then convene an exceptional meeting to consider the report, if a majority of the members wish to do so, or the report shall be submitted to the next meeting of the General Assembly or the Commission (whichever comes first).

This proposal was contained in the annex to the Commission's resolution on the subject. The resolution was cosponsored by twenty-nine members (a majority) of the Commission, and by thirteen observer governments. ${ }^{298} \mathrm{Sev}$ eral members of the Commission, including Cuba, India, Mexico, and Pakistan, were uncomfortable taking action on such an important mechanism

297. Some progress was also made in 1990 when ECOSOC gave permission for the Commission to meet on an exceptional basis between sessions to address urgent human rights situations, provided that a majority of the members so desire. E.S.C. Res. 1990/48, U.N. Doc. E/ $1990 / \mathrm{INF} / 6$ at $80(1990)$.

298. C.H.R. Res. 1992/55, 48 U.N. ESCOR Supp. (No.2) at 131, U.N. Doc. E/CN.4/1992/84 (1992). 
without thoroughly considering all of its ramifications. As a result, India proposed an amendment which deferred consideration of the mechanism until next year. After some initial attempts to push its proposal through at the Commission, Austria decided take the diplomatic approach of accepting India's amendment as part of its own resolution, in the hope of allowing further consideration of the mechanism and building consensus for next year. Accordingly, India withdrew its amendments and the Commission's resolution taking note of the proposed mechanism and deciding to continue to examine the mechanism next year was approved by consensus, as amended.

There have, in fact, been two requests to convene an emergency session of the Commission since the end of the 1992 session. In July 1992, the Arab Member States lobbied for an emergency session to examine the human rights situation in the Israeli-Occupied Territories. The attempt failed, however, as a number of delegations believed the situation in the Occupied Territories had not significantly changed and thus did not justify convening an emergency session.

The Commission did, however, convene an emergency session on the human rights situation in the former Yugoslavia on 13-14 August 1992, at the request of the United States Representative to the United Nations in Geneva, Ambassador Morris B. Abram. The emergency session concluded with the adoption of a lengthy resolution which included, inter alia, a request to the Chair of the Commission to appoint a Special Rapporteur to investigate first-hand the human rights situation in the territory of the former Yugoslavia, in particular within Bosnia-Herzegovina. ${ }^{299}$ The Chair appointed Tadeusz Mazowiecki (Poland) who was asked to provide a preliminary report no later than 28 August $1992 .{ }^{300}$ Mazowiecki, who was accompanied by several UN Human Rights Centre staff, left promptly for the former Yugoslavia.

\section{F. Fair Trial}

Last year, the Commission endorsed the decision of the Sub-Commission to authorize its two Special Rapporteurs on the right to a fair trial, Stanislav Chernichenko (Russia) and William Treat (United States), to pursue an in-

299. U.N. Doc. E/CN.4/1992/S-1/L.2 (13 Aug. 1992). The Commission's decision paralleled Resolution 771 of the U.N. Security Council condemning "any violations of international humanitarian law including those involved in the practice of "ethnic cleansing.' " U.N. Doc. S/RES/771 (1992). The Security Council also called upon governments and international humanitarian organizations to collate substantiated information relating to violations of humanitarian law and to make this information available to the Council. Id.; see also, e.g., U.N. Doc. S/RES/770 (1992) (demanding that unimpeded access to all camps, prisons, detention centers be granted immediately to the Red Cross and other relevant humanitarian organizations).

300. U.N. Doc. E/CN.4/1992/S-1/L.2 (13 Aug. 1992). 
depth study on the subject. ${ }^{301}$ This year's resolution endorses the continued work of the two Special Rapporteurs on the subject, requests the SecretaryGeneral to submit questionnaires to those governments and organizations that have not yet responded to the previous questionnaire, and requests the Special Rapporteurs take into account the reports of states to treaty-monitoring bodies relevant to the right to fair trial..$^{302}$

The resolution also thanks the Special Rapporteurs for their second report ${ }^{303}$ on the right to fair trial, and looks forward to the submission of a third report next year (on the interpretations of international organizations on the right to fair trial and a preliminary analysis of responses to the revised questionnaire) and fourth and fifth reports, containing a more complete analysis of the responses to the questionnaires, and recommendations for strengthening the right to fair trial, respectively. The second report was wellreceived, with compliments from such delegations as Australia and Austria. Canada pointed out ${ }^{304}$ that the report broke new ground with respect to a right that had been a norm of international human rights law for over forty years. Finally, the resolution contemplates the possibilities of strengthening the right to fair trial by, for example, making aspects of the right nonderogable, and by incorporating basic fair trial guarantees into an international standard, such as a model code. ${ }^{305}$

\section{G. Advisory Services}

There has been a significant increase in the number of requests for advisory services $^{306}$ including expert advice, fellowships, scholarships, seminars, and training courses. ${ }^{307}$ During 1991, the Centre for Human Rights provided resource persons or sent participants to over 100 seminars, training courses, or meetings organized by other organizations. Eight training courses and workshops were organized in cooperation with governments and national institutions. ${ }^{308}$

The Secretary-General's 1992 report on the program of advisory services

301. C.H.R. Res. 1991/43, 47 U.N. ESCOR Supp. (No.2) at 107, U.N. Doc. E/CN.4/1991/91 (1991).

302. C.H.R. Res. 1992/34, 48 U.N. ESCOR Supp. (No.2) at 90, U.N. Doc. E/CN.4/1992/84 (1992).

303. U.N. Doc. E/CN.4/Sub.2/1991/29 (1991).

304. Intervention of Canadian delagate of 12 February 1992.

305. C.H.R. Res. 1992/34, 48 U.N. ESCOR Supp. (No.2) at 90, U.N. Doc. E/CN.4/1992/84 (1992).

306. U.N. Press Release HR/3048 (27 Feb. 1992), at 3.

307. U.N. Doc. E/CN.4/1992/49 (1992), at 3.

308. These training courses and workshops took place in Jakarta, Sofia, Windhoek, Ouagadougou, Moscow, Nuuk, Paris, and Geneva. U.N. Press Release HR/3048 (27 Feb. 1992), at 2 . 
detailed the advisory service activities of the preceding year. ${ }^{309}$ The report highlighted such programs as the Centre's education and training activities in Cambodia, working primarily under the auspices of the United Nations Transitional Authority in that country. ${ }^{310}$ Since 1988, a "prime focus" of advisory services has been the process of democratization, which has led the Centre for Human Rights to organize a number of activities in Central and Eastern Europe, in particular. These activities include drafting of constitutions (e.g., in Bulgaria, Mongolia, Paraguay, Romania, and to a certain extent in South Africa), providing expert advice on holding free and fair elections (e.g., in Albania, Bulgaria, Lesotho, and Romania), and assisting with drafting new legislation in conformity with international human rights norms. ${ }^{311}$ Under-Secretary-General for Human Rights Jan Martenson called attention to this new emphasis in his introduction of the advisory services item of the Commission's agenda. ${ }^{312}$ (Such activities are usually funded through the Voluntary Fund for Technical Cooperation, while the provision of expert assistance requested by specific Commission resolution, as in the cases of Haiti or Guatemala, for example, is usually funded through the regular United Nations budget.)

The members and observers speaking on the subject of advisory services were generally quite complimentary of advisory services work performed by the Centre. The crucial role of the Centre for Human Rights was emphasized as a clearing house for coordination of technical assistance from other organizations in the United Nations system and with nongovernmental organizations. ${ }^{313}$ Several states did mention, however, that improvements could be made in evaluating and following up the results of advisory services rendered.

During the Commission discussion on advisory services, both governmental and nongovernmental organizations made the point that advisory services should be seen by countries as complementary to, and not a substitute for, other human rights initiatives and procedures. Both the investigation and monitoring function, on the one hand, and the technical assistance function, on the other hand, are legitimate and important functions. The provision of advisory services is certainly not intended to exempt govern-

309. U.N. Doc. E/CN.4/1992/49 (1992).

310. Id. at 5.

311. Id.

312. See U.N. Press Release HR/3048 (27 Feb. 1992), at 2.

313. Particular nongovernmental organizations mentioned in the Secretary-General's Report on Advisory Services were Amnesty International, the Andean Commission of Jurists, the International Commission of Jurists, the Lawyers Committee for Human Rights, the Caribbean Human Rights Network, the International Human Rights Law Group, and the Minnesota Lawyers International Human Rights Committee. See U.N. Doc. E/CN.4/1992/49 (1992), at 12. 
ments from continued scrutiny, although some governments attempt to misuse advisory service in that way.

Regarding advisory services funded from the regular budget, the Commission's 1992 resolution reiterates the importance of the "clearing-house" role of the Centre, affirms the practical assistance provided by advisory services, welcomes the increased requests from governments for such services, encourages still more governments to make use of the services, suggests concise reporting on activities in order to facilitate follow-up and evaluation, and urgently requests financial assistance from the Secretary-General to deal with the increased demand. ${ }^{314}$ Regarding those services funded from the voluntary fund, the resolution thanks those states that have contributed to the fund, reiterates the importance of voluntary fund activities in strengthening national institutions for implementing human rights standards, and encourages model projects for legal protection and the strengthening of judicial independence as core projects of the voluntary fund. ${ }^{315}$ The resolution left in doubt how advisory services funded from the regular UN budget would be coordinated with advisory services funded from the voluntary fund.

\section{H. Draft Declaration on Human Rights Defenders}

Since 1984 the Commission has had an open-ended Working Group to draft a declaration on "the right and responsibility of individuals, groups and organs of society to promote and protect universally recognized human rights and fundamental freedoms." This convoluted phrase is meant to refer mainly to human rights defenders. The problem, of course, is that the very defenders of human rights in various countries are so often subject to violations themselves. The report of that working group was before the Commission, along with the first reading text of a declaration, which was well received by the Commission. ${ }^{316}$

The Working Group had taken a long time to get to this stage, primarily because of the presence of representatives from several repressive governments, who reportedly delayed progress at each stage..$^{317}$ In its resolution on the subject, the Commission expressed its wish that the Working Group complete its task and submit the Draft Declaration to the Commission next

314. C.H.R. Res. 1992/80, 48 U.N. ESCOR Supp. (No.2) at 198, U.N. Doc. E/CN.4/1992/84 (1992).

315. 1 d.

316. U.N. Doc. E/CN.4/1992/53 (1992).

317. Zoller, supra note 1 , at 12 . 
year. ${ }^{318}$ To that end, the resolution instructed that the report is to be sent to the governments of all member states of the United Nations, and to interested intergovernmental and nongovernmental organizations, for comments. ${ }^{319}$ It is thus possible, and perhaps even probable, that the Draft Declaration will be adopted at next year's Commission.

\section{Draft Optional Protocol to Torture Convention}

The Commission made progress towards a Draft Optional Protocol to the Convention Against Torture and other Cruel, Inhuman or Degrading Treatment or Punishment. The Optional Protocol would establish a system of preventive visits to places of detention.

This idea apparently originated with the Geneva banker Jean-Jacques Gautier, who believed that such a system would be effective in the fight against torture. ${ }^{320}$ Costa Rica picked up the idea and submitted a draft text in 1980, but the idea of the preventive visits was put on hold while the effort to adopt the Torture Convention itself was made. Upon adoption of that Convention in 1990, and after a couple of years experience with the Committee Against Torture, Costa Rica decided to reintroduce its proposal in the form of an optional protocol. The Special Rapporteur on Torture endorsed the idea of a treaty-based system of preventive visits in his report to the Commission.

The draft was extremely well received at the Commission. Many governments, including Belgium, Chile, Italy, Liechtenstein, Norway, Poland, Portugal, Russia, Sweden, Switzerland, and NGOs spoke in favor of the draft, especially its thrust toward prevention of human rights violations before they occur. European delegations as well as several NGOs referred to the positive experience with the similar mechanism that exists on the regional level through the European Convention.

The Commission's resolution creates an intersessional Working Group to meet in Autumn 1992 "to elaborate a draft optional protocol to the Convention Against Torture, using as a basis for its discussions the draft text proposed by the Government of Costa Rica." ${ }^{121}$ In the meantime, governments and interested NGOs are asked to comment on the draft text.

Although Australia, Colombia, and Peru voiced objections to the proposal in its current form, Peru did mention after adoption of the consensus resolution that it would take part in the Working Group.

318. C.H.R. Res. 1992/82, 48 U.N. ESCOR Supp. (No.2) at 205, U.N. Doc. E/CN.4/1992/84 (1992).

319. Id.

320. Zoller, supra note 1 , at 12 .

321. C.H.R. Res. 1992/43, 48 U.N. ESCOR Supp. (No.2) at 205, U.N. Doc. E/CN.4/1992/84 (1992). 


\section{J. Fact-finding and Forensic Science}

In a move aimed at reinforcing international fact-finding, especially in cases of disappearances or summary/arbitrary executions, the Commission adopted a resolution noting the proposed model autopsy protocol prepared by the Minnesota Lawyers International Human Rights Committee (the "Minnesota Protocol"), and suggesting that a standing team of forensic scientists be recruited on a voluntary basis, and referred to governments who have a need for assistance in exhumation and identification of victims of human rights violations, or in the training of local teams for the same purposes. ${ }^{322}$ Many countries do not have sufficient forensic expertise. The resolution thus requests that the Secretary-General study the practical and financial viability of such a project, and begin to develop workable arrangements for its management. After the consensus adoption of the resolution, China expressed its reservations that in China and other cultures, exhumation could be a sign of disrespect and offensive to the relatives of the deceased. China asked that its reservations be made a part of the record.

Sponsored by Russia, the resolution was furthered by the persuasive presence on the United States delegation of renowned forensic scientist Dr. Clyde Snow, who has assisted in exhumation and identification of remains of victims of human rights violations in such situations as Argentina's "dirty war," the armed conflict in Guatemala, and the killing of Kurds in northern Iraq.

\section{K. AIDS and other Disabilities}

The Commission welcomed the preliminary and progress reports $\mathrm{s}^{323}$ of the Sub-Commission's Special Rapporteur Luis Varela Quiros (Costa Rica) on discrimination against persons with the AIDS virus and also persons who had tested HIV positive. The Commission adopted by consensus a resolution that called on states to take all necessary steps to ensure that such persons are guaranteed full enjoyment of their human rights. ${ }^{324}$ The resolution emphasized that there must be an end to the "social stigmatization and discrimination against those infected by HIV and AIDS, their families and those with whom they live, and people considered to be at risk of infection."

In a related resolution, the Commission endorsed the report of SubCommission Special Rapporteur Leandro Despouy (Argentina) on human rights of persons with disabilities, although the Commission stopped short

322. C.H.R. Res. 1992/24, 48 U.N. ESCOR, Supp. (No.2) at 71, U.N. Doc. E/CN.4/1992/84 (1992).

323. U.N. Doc. E/CN.4/1990/9 (1990) and U.N. Doc. E/CN.4/Sub.2/191/10 (1991).

324. C.H.R. Res. 1992/56, 48 U.N. ESCOR Supp. (No.2) at 134, U.N. Doc. E/CN.4/1992/84 (1992). 
of calling for a new mechanism in the area. ${ }^{325}$ The Commission did urge the widest possible circulation of the report, including making sure that it was available in braille, on tape, and on computer diskettes.

\section{Other}

\section{Functioning of Treaty Bodies}

The Commission had before it the Secretary-General's report on the comments of the treaty bodies on long-term approaches to their effective functioning ${ }^{326}$ In the Commission's standard resolution on this subject, adopted by consensus, the Commission (1) urged state parties to the various international human rights treaties to submit their reports on a timely basis, in light of the "continuing and increasing backlog of reports on implementation," (2) continued to support the "institutionalization" of the meetings of the Chairs of the treaty bodies, (3) requested the General Assembly and the Secretary-General to ensure adequate short and long-term financial resources for the functioning of the treaty bodies, and the meetings of the Chairs of the treaty bodies, using the regular budget of the United Nations where possible, and (4) urged the Secretary-General to "give priority" to implementing the recommendations of the Task Force on Computerization of the reporting process (whereas the previous year's resolution had merely asked him to "expedite" such implementation). ${ }^{327}$ Other significant differences between the 1992 resolution and the 1991 version were that (1) the new resolution contains a request that the meeting of persons chairing the human rights treaty bodies in 1992 include on its agenda the question of reservations to human rights instruments and their legal effect-a question of particular importance to the United States as it continues to debate whether to ratify the major international human rights instruments to which it has not yet acceded, and (2) requests the Secretary-General to ensure that the periodic reports of states submitted in connection with treaty compliance are made available in the United Nations information centers in those countries.

\section{Status of International Instruments}

The Commission adopted its usual resolutions urging those states that have not yet acceded to or ratified the primary international human rights

325. C.H.R. Res. 1992/48, 48 U.N. ESCOR Supp. (No.2) at 116, U.N. Doc. E/CN.4/1992/84 (1992).

326. U.N. Doc. E/CN.4/1992/44 (1992).

327. C.H.R. Res. 1992/15, 48 U.N. ESCOR Supp. (No.2) at 50, U.N. Doc. E/CN.4/1992/84 (1992). 
instruments, to do so. These instruments include the two International Covenants on Civil and Political Rights and Economic, Social and Cultural Rights, as well as the Convention Against Torture, the Migrant Workers Convention, the Convention on the Rights of the Child, and the Convention on Mercenaries.

\section{Protection of Gypsies (Roma)}

The Commission adopted its first-ever resolution guaranteeing the rights of a specific minority, when it adopted a resolution urging states to protect Roma (gypsies) in their territory. ${ }^{328}$ The German delegation, acting on instructions from Bonn with obvious discomfiture, first offered clumsy and unintelligible amendments that were intended to water down the resolution, and then insisted on a vote on this item. Germany's explanation of its vote before the vote was as clumsy as its attempts to amend the resolution; Germany rather insensitively stated that it did not consider the Roma a minority, but often "illegal persons" subject to being expelled by a country if illegally present. The United States explained, more persuasively, that it would abstain on the ground that it was inadvisable to specify that particular minorities are protected against discrimination, when international law already protects all people within states from discrimination. Although it is difficult to imagine why Germany insisted on a vote that only served to embarrass itself before the Commission, the resolution was adopted by a vote of forty-three votes to none, with eight (including Germany and the United States) abstaining.

\section{Nagorno Karabagh}

The Commission saw much activity regarding Nagorno Karabagh during its session, including the interventions of a large number of NGOs and a well attended meeting with Caroline Cox from the British House of Lords and Zori Balayan from the Karabagh Parliament. Although a draft declaration on the situation was circulated, the Commission members were not persuaded to take action during the session. A consensus statement was to have been read at the very end of the session, but Turkey apparently objected to the "interference in the internal affairs of Azerbaijan." 329

\section{Miscellaneous}

In other actions, the Commission adopted its more or less standard resolutions on subjects as diverse as dissemination of information concerning

328. C.H.R. Res. 1992/65, 48 U.N. ESCOR Supp. (No.2) at 152, U.N. Doc. E/CN.4/1992/84 (1992).

329. Zoller, supra note 1 , at 22 . 
human rights standards and United Nations activities, ${ }^{330}$ and hostage taking. ${ }^{331}$

The effects of the Persian Gulf War continued to be felt in a number of areas affecting human rights, including cases of arbitrary and summary executions, disappearances, torture, and environmental destruction, as indicated by numerous references to the war in various thematic and other reports of the Commission.

\section{CONCLUSION}

The 1992 session of the Commission was the most effective and productive in years. The Commission acted on more country situations than ever before. A number of countries (e.g., Cuba, East Timor, Equatorial Guinea, Haiti, Iran, Myanmar, Somalia, Sudan, and Zaire) were subjected to new or increased scrutiny. In addition, significant developments in standard-setting were made, including the promulgation of new draft declarations on $\mathrm{Mi}$ norities and Disappearances, as well as progress toward the Optional Protocol on Torture and the Draft Declaration on Human Rights Defenders. The Commission confirmed that all thematic mechanisms have a three-year mandate adding an element of confidence to both the independence and thoroughness of those mechanisms. Furthermore, the protection of human rights may be enhanced by the decline of ideological considerations and significant steps toward reform of the Commission and its Sub-Commission.

Nonetheless, from the opening statement by Enrique Bernales Ballesteros (Peru), it was evident that the new international situation is fraught with challenges as well as opportunities. The persistence of armed conflict and ethnic strife are significant challenges facing the Commission in its worldwide protection of human rights. ${ }^{332} \mathrm{~A}$ similar challenge lies in the continuing North-South political division between developed and developing nations. The increased activity of the United Nations, however, and the ability of the Commission to respond promptly give reason for optimism about the future.

330. C.H.R. Res. 1992/38, 48 U.N. ESCOR Supp. (No.2) at 95, U.N. Doc. E/CN.4/1992/84 (1992).

331. C.H.R. Res. 1992/23, 48 U.N. ESCOR Supp. (No.2) at 70, U.N. Doc. E/CN.4/1992/84 (1992).

332. U.N. Press Release HR/3005 (27 Jan. 1992), at 1-2. 